


\section{Bedrijfsuitkomsten in de Nederlandse particuliere bosbouw over 2018}

H.J. Silvis en M.J. Voskuilen 
Silvis, H.J. en M.J. Voskuilen, 2020. Bedrijfsuitkomsten in de Nederlandse particuliere bosbouw over 2018. Wageningen, Wageningen Economic Research, Rapport 2020-048. 48 blz.; 10 fig.; 16 tab.; 8 ref.

Dit rapport biedt een overzicht van de bedrijfsresultaten van particuliere bosbedrijven in 2018. Hierbij gaat het om particuliere boseigenaren met meer dan 50 ha bos, met uitzondering van de particuliere natuurbeschermingsorganisaties. De Nederlandse particuliere bosbedrijven hebben in 2018 een bedrijfsresultaat geboekt van gemiddeld 22 euro per ha bos, tegen -3 euro in 2017 . Dit is te danken aan hogere opbrengsten ( $+7 \%$ ) en lagere kosten (-2\%). De opbrengsten-kostenverhouding is in 2018 uitgekomen op $108 \%$, tegen $99 \%$ in 2017.

Trefwoorden: bosbouw, bedrijfsresultaten, opbrengsten, kosten, bedrijfsgrootte, regio

Dit rapport is gratis te downloaden op https://doi.org/10.18174/524752 of op www. wur. nl/economicresearch (onder Wageningen Economic Research publicaties).

(C) 2020 Wageningen Economic Research

Postbus 29703, 2502 LS Den Haag, T 07033583 30, E communications.ssg@wur.nl, www.wur.nl/economic-research. Wageningen Economic Research is onderdeel van Wageningen University \& Research.

\section{(cc) BY-NC}

Dit werk valt onder een Creative Commons Naamsvermelding-Niet Commercieel 4.0 Internationaallicentie.

(C) Wageningen Economic Research, onderdeel van Stichting Wageningen Research, 2020

De gebruiker mag het werk kopiëren, verspreiden en doorgeven en afgeleide werken maken. Materiaal van derden waarvan in het werk gebruik is gemaakt en waarop intellectuele eigendomsrechten berusten, mogen niet zonder voorafgaande toestemming van derden gebruikt worden. De gebruiker dient bij het werk de door de maker of de licentiegever aangegeven naam te vermelden, maar niet zodanig dat de indruk gewekt wordt dat zij daarmee instemmen met het werk van de gebruiker of het gebruik van het werk. De gebruiker mag het werk niet voor commerciële doeleinden gebruiken.

Wageningen Economic Research aanvaardt geen aansprakelijkheid voor eventuele schade voortvloeiend uit het gebruik van de resultaten van dit onderzoek of de toepassing van de adviezen.

Wageningen Economic Research is ISO 9001:2015 gecertificeerd.

Wageningen Economic Research Rapport 2020-048 | Projectcode 2282200546

Foto omslag: Shutterstock 


\section{Inhoud}

Woord vooraf $\quad 5$

$\begin{array}{ll}\text { Samenvatting } & 6\end{array}$

S.1 Belangrijkste uitkomsten $\quad 6$

$\begin{array}{lll}\text { S.2 Overige uitkomsten } & 7\end{array}$

$\begin{array}{ll}\text { S.3 Methode } & 7\end{array}$

\begin{tabular}{l|rr}
1 & Resultaten van bosbedrijven & 8
\end{tabular}

$\begin{array}{lll}1.1 & \text { Bedrijfsresultaten } & 8\end{array}$

1.2 Opbrengsten $\quad 8$

$\begin{array}{lll}1.3 & \text { Houtprijs en oogstvolume } & 9\end{array}$

$\begin{array}{llr}1.4 & \text { Kostensoorten } & 10\end{array}$

$\begin{array}{lll}1.5 & \text { Kostenplaatsen } & 11\end{array}$

1.6 Spreiding in resultaten $\quad 12$

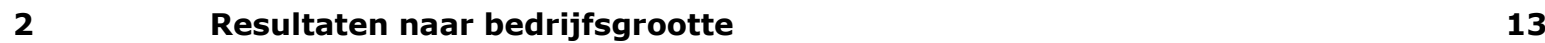

2.1 Bedrijfsresultaten $\quad 13$

2.2 Opbrengsten 14

$\begin{array}{lll}2.3 \text { Kosten } & 15\end{array}$

$\begin{array}{llr}3 & \text { Resultaten naar regio } & 17\end{array}$

$\begin{array}{lll}3.1 & \text { Bedrijfsresultaten } & 17\end{array}$

$\begin{array}{lll}3.2 & \text { Opbrengsten } & 17\end{array}$

$\begin{array}{lll}3.3 & \text { Kosten } & 18\end{array}$

$4 \quad$ Resultaten op lange termijn $\quad 20$

$\begin{array}{lll}4.1 & \text { Bedrijfsresultaten } & 20\end{array}$

$\begin{array}{lll}4.2 & \text { Kosten en opbrengsten } & 20\end{array}$

4.3 Houtprijzen en oogstvolume $\quad 22$

$\begin{array}{ll}\text { Literatuur en websites } & 24\end{array}$

Bijlage 1 Verantwoording $\quad 25$

$\begin{array}{lll}\text { Bijlage } 2 & \text { Tabellen } & 32\end{array}$ 



\section{Woord vooraf}

De monitoring van de bedrijfseconomische aspecten van het bosbeheer gebeurt onder meer ten behoeve van het beleid van de overheid. Dit jaar wil de minister van Landbouw, Natuur en Voedselkwaliteit (LNV) samen met provincies een Bossenstrategie met een uitvoeringsprogramma en de daarbij behorende instrumenten vaststellen. Hoofdthema's zijn onder andere uitbreiding van het bosareaal en het verbeteren van de vitaliteit van het bos. Bij de houtoogst gaat de hoogwaardige toepassing van hout voor, en wordt een lichte toename van de oogst mogelijk geacht.

Dit rapport geeft een overzicht van de bedrijfsresultaten, opbrengsten en kosten van particuliere bosbedrijven met meer dan 50 ha bos. De resultaten in 2018 worden afgezet tegen die in de voorafgaande jaren. In de bijlage zijn ook de resultaten van bedrijven met minder dan 50 ha bos opgenomen.

In aanvulling op de gemiddelde resultaten van de onderscheiden bedrijven, gaat het rapport in op de resultaten naar grootte van het bosbezit (50-100 ha, 100-250 ha en 250 ha en meer) en naar regio (Noordoost, Centrum en Zuid). Ten slotte worden de reële resultaten op lange termijn (1975-2018) geschetst. De verantwoording van doel en opzet van het onderzoek en de toelichting op de gehanteerde begrippen en rekenregels zijn opgenomen in de bijlagen.

Namens LNV is ir. Peter van der Knaap, beleidsmedewerker natuur en biodiversiteit, opgetreden als contactpersoon. Graag bedanken we hem voor de constructieve samenwerking.

Veel dank is verschuldigd aan de eigenaren en beheerders van particuliere bosbezittingen die, door het ter beschikking stellen van bedrijfsgegevens, deze publicatie mogelijk hebben gemaakt. De dataverzameling is verzorgd door Jeroen Bremer, René van den Broek, Henk Nuijen, Gunther Tap en Roel van der Velde.

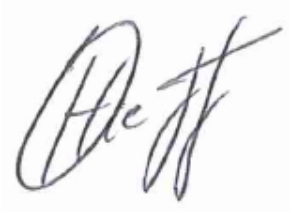

Ir. O. Hietbrink, Olaf

Business Unit Manager Wageningen Economic Research Wageningen University \& Research

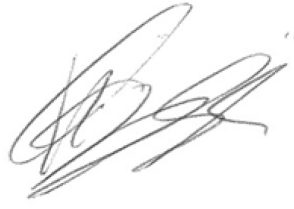

Dr. H.C.J. Vrolijk Hoofd WOT Economische Informatievoorziening 


\section{Samenvatting}

\section{S.1 Belangrijkste uitkomsten}

De Nederlandse particuliere bosbedrijven (groter dan 50 ha) sloten 2018 af met een positief bedrijfsresultaat van gemiddeld 22 euro per ha bos (tabel S.1). In 2017 was een klein verlies geleden van 3 euro per ha. Het resultaat is te danken aan hogere opbrengsten $(+7 \%)$ en lagere kosten $(-2 \%)$. De opbrengsten-kostenverhouding kwam in 2018 uit op 108\%, tegen 99\% in 2017.

Tabel S.1 Resultaten (euro per ha bos), 2014-2018

\begin{tabular}{lrrrrr} 
& 2014 & 2015 & 2016 & 2017 & 271 \\
Opbrengsten & 280 & 271 & 275 & 275 & 274 \\
\hline Kosten & 239 & 233 & 268 & -3 & 22 \\
\hline Bedrijfsresultaat & 40 & 38 & 111 & 99 \\
\hline Opbrengsten/kosten (\%) & 117 & 116 & 41 & 11 \\
\hline Inkomen uit het bosbedrijf & 54 & 52 & 35 \\
\hline
\end{tabular}

Bron: Bedrijveninformatienet, Wageningen Economic Research.

Het gemiddelde inkomen uit het bosbedrijf - het bedrijfsresultaat plus de berekende arbeidsvergoeding (in hoofdzaak van de eigenaar) - bedroeg 35 euro per ha in 2018, tegenover 11 euro per ha in 2017.

Gecorrigeerd voor inflatie laat het gemiddelde bedrijfsresultaat van particuliere bosbedrijven (groter dan 50 ha) over de gehele waarnemingsperiode van 1975-2018 een positieve trend zien (figuur S.1). In de periode 1975-1990 was het gemiddelde resultaat 31 euro per ha negatief, maar werd het verlies sterk verminderd. In de jaren 1991-2005 - een meer stabiele periode - werd gemiddeld 22 euro verlies geleden. Vanaf 2006 zijn op twee jaar na alle jaren met een positief resultaat afgesloten; gemiddeld is tussen 2006 en 2018 een positief resultaat geboekt van 42 euro per ha bos. De betere resultaten waren vooral te danken aan hogere houtopbrengsten.

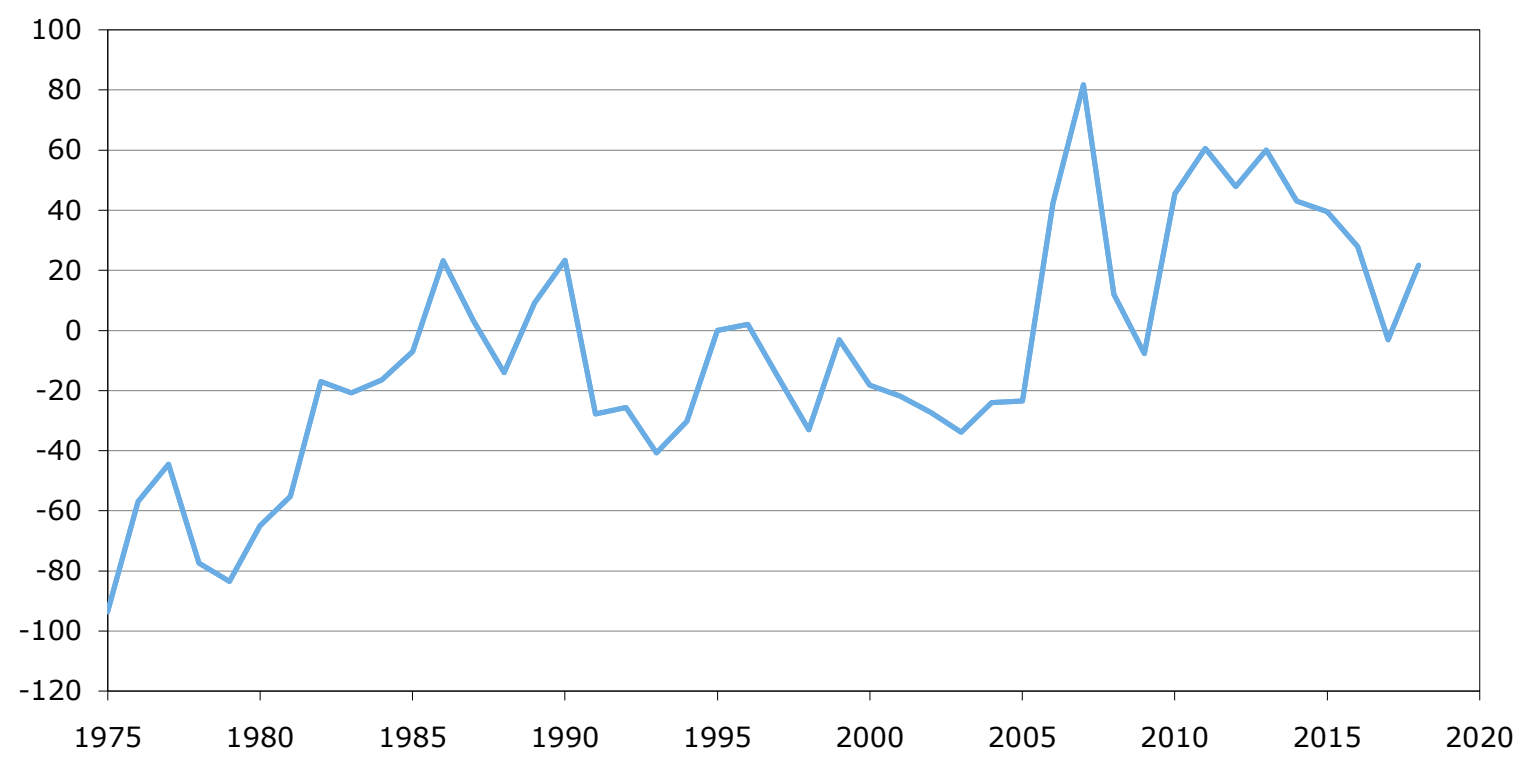

Figuur S.1 Gemiddeld reëel bedrijfsresultaat per ha bos (in euro's van 2018), 1975-2018 Bron: Bedrijveninformatienet, Wageningen Economic Research. 


\section{S.2 Overige uitkomsten}

Over het algemeen lopen de bedrijfsresultaten op bij een toenemende bedrijfsomvang (ha bos), maar de spreiding binnen de grootteklassen is groot. De kleine bedrijven (50-100 ha bos) boekten in 2018 een gemiddeld verlies van 13 euro per ha en de middelgrote (100-250 ha) en grote bedrijven (250 ha bos of meer) een winst van rond 30 euro per ha. De gemiddelde opbrengsten-kostenverhouding varieerde tussen $95 \%$ op de kleine bedrijven tot rond de $110 \%$ op de middelgrote en grote bedrijven. In de periode 2014-2018 boekte gemiddeld 49\% van de kleine bedrijven een positief resultaat. Voor de middelgrote bedrijven was dat $55 \%$, voor de grote bedrijven $61 \%$.

De kleine bedrijven hebben het verlies ten opzichte van de gemiddelde resultaten in de vier voorgaande jaren (2014-2017) teruggebracht door de kosten te drukken. Op de middelgrote en grote bedrijven daalde het resultaat in 2018 door hogere kosten. Het inkomen uit het bosbedrijf - het bedrijfsresultaat plus de berekende vergoeding van de eigen arbeid - steeg op de kleine bedrijven naar 21 euro per ha bos in 2018, tegenover -5 euro per ha in de voorafgaande 2014-2017. Het inkomen van de middelgrote bedrijven kwam in 2018 uit op 49 euro per ha en dat van de grote bedrijven op 34 euro per ha.

De bosbedrijven in de drie onderscheiden regio's (Noordoost, Zuid en Centrum) vertonen verschillen qua bedrijfsvoering en bedrijfsresultaten. In de regio Zuid zijn de gemiddelde opbrengsten en kosten van het bosbeheer relatief laag, zowel door een lagere houtoogst als door minder subsidies. In de regio's Noordoost en Zuid waren de bedrijfsresultaten van respectievelijk 31 euro en 25 euro per ha in 2018 hoger ten opzichte van het gemiddelde in de jaren 2014-2017. In beide regio's stegen de opbrengsten harder dan de kosten: de opbrengsten-kostenverhouding kwam in de regio Noordoost uit op $110 \%$ en in Zuid op $114 \%$. In de regio Centrum liep het bedrijfsresultaat echter vrij sterk terug van 35 tot 7 euro per ha door lagere opbrengsten en hogere kosten: de rentabiliteit daalde hierdoor van 114 naar $102 \%$.

\section{S.3 Methode}

De jaarlijkse publicatie van Wageningen Economic Research over de bedrijfsuitkomsten in de Nederlandse particuliere bosbouw verschijnt op verzoek van het ministerie van Landbouw, Natuur en Voedselkwaliteit. De publicatie verschaft informatie over de bedrijfsresultaten (in euro per ha bos) van particuliere bedrijven. Hierbij gaat het om particuliere boseigenaren, met uitzondering van de natuurbeschermingsorganisaties. De resultaten zijn gebaseerd op het Bedrijveninformatienet van Wageningen Economic Research (zie bijlage 1). De administraties hebben alleen betrekking op de resultaten van het bosbedrijf. Met de vergelijking van de jaarlijkse uitkomsten moet voorzichtig worden omgegaan, omdat de bedrijfsvoering in het bos op de lange termijn is gericht en de werkzaamheden (beheer, verjonging, onderhoud, vellingen) niet steeds gelijkmatig over de jaren gespreid zijn. 


\section{Resultaten van bosbedrijven}

\subsection{Bedrijfsresultaten}

Gemiddelde bedrijfsresultaten positief

De Nederlandse particuliere boseigenaren met meer dan 50 ha bos hebben 2018 afgesloten met een positief bedrijfsresultaat (saldo van opbrengsten en kosten) van gemiddeld 22 euro per ha bos (tabel 1.1). Dat is ruim boven het resultaat van 2017 door hogere opbrengsten $(+7 \%)$ en iets $(-2 \%)$ lagere kosten. De opbrengsten-kostenverhouding is in 2018 uitgekomen op 108\%, tegen 99\% in 2017.

Tabel 1.1 Resultaten (euro per ha bos), 2014-2018

\begin{tabular}{|c|c|c|c|c|c|}
\hline & 2014 & 2015 & 2016 & 2017 & 2018 \\
\hline Opbrengsten & 280 & 271 & 272 & 271 & 289 \\
\hline Kosten & 239 & 233 & 245 & 274 & 268 \\
\hline Opbrengsten/kosten (\%) & 117 & 116 & 111 & 99 & 108 \\
\hline Inkomen uit het bosbedrijf & 54 & 52 & 41 & 11 & 35 \\
\hline
\end{tabular}

Bron: Bedrijveninformatienet, Wageningen Economic Research.

\section{Beperkte inbreng eigen arbeid}

Het inkomen uit het bosbedrijf is in 2018 uitgekomen op 35 euro per ha per bos, tegen 11 euro per ha in 2017 (tabel 1.1). Het inkomen uit het bosbedrijf, de beloning van de eigenaar voor risico, management en arbeid, wordt berekend door het bedrijfsresultaat te vermeerderen met de berekende arbeidskosten van de eigenaar (zie bijlage 1.6) en de overige berekende lonen (die laatste zijn te verwaarlozen). De inbreng van de eigen arbeid (per ha) van de boseigenaar is vrij klein en daarmee ook de bijdrage aan het inkomen. De hiervoor in rekening gebrachte bedragen waren in de afgelopen vijf jaar gemiddeld $5 \%$ à $6 \%$ van de totale kosten.

\subsection{Opbrengsten}

Toename houtopbrengsten

De gemiddelde opbrengsten van de particuliere bosbedrijven zijn in 2018 met 7\% gestegen, van 271 euro in 2017 tot 289 euro per ha in 2018 (tabel 1.2). Dat is ook ruim boven het gemiddelde in de periode 2014-2017.

Tabel 1.2 Opbrengsten (euro per ha bos), 2014-2018

\begin{tabular}{|c|c|c|c|c|c|}
\hline & 2014 & 2015 & 2016 & 2017 & 2018 \\
\hline Hout & 136 & 129 & 136 & 126 & 142 \\
\hline w.o. Op stam & 121 & 114 & 116 & 111 & 130 \\
\hline Beheersubsidie & 81 & 77 & 77 & 77 & 85 \\
\hline Overige subsidies & 15 & 10 & 16 & 28 & 14 \\
\hline Recreatie & 15 & 15 & 15 & 13 & 17 \\
\hline Overig & 15 & 22 & 11 & 11 & 15 \\
\hline Totaal & 280 & 271 & 272 & 271 & 289 \\
\hline
\end{tabular}

Bron: Bedrijveninformatienet, Wageningen Economic Research. 
De toename van de opbrengsten in 2018 is mede te danken aan de hogere houtopbrengsten. Deze stegen met $13 \%$ (ten opzichte van 2017) tot 142 euro per ha bos. Dit kwam door de hogere houtprijs en een groter oogstvolume (zie paragraaf 1.3). In 2018 bedroegen de houtopbrengsten $49 \%$ van de totale opbrengsten (figuur 1.1), vrijwel gelijk aan het niveau in de periode 2014-2017.

\section{Subsidies iets hoger}

De totale subsidies namen in 2018 ook iets toe: 99 euro per ha tegen gemiddeld 95 euro per ha per jaar in de periode 2014-2017. Daarmee zijn ze goed voor 34\% van de totale opbrengsten (figuur 1.1), wat vrijwel gelijk is aan de gemiddelde bijdrage van de subsidies in de periode 2014-2017.

Het grootste deel (ruim 80\% tussen 2014-2018) van de subsidies bestaat uit een structurele bijdrage aan de beheerkosten van het bos via Subsidiestelsel Natuur en Landschap (SNL), waaronder een openstellingsbijdrage. De bijdrage aan de directe werkzaamheden natuur- en landschapsbeheer wordt bepaald op basis van de 'standaardkostprijs' die per type natuurtype wordt berekend. De SNL-tarieven bedragen een percentage (doorgaans 75\%) van deze kostprijs. Met ingang van 2018 zijn de tarieven voor 'droog bos met productiefunctie' en 'vochtig bos met productiefunctie' verhoogd tot respectievelijk circa 25 euro en 45 euro per ha. In de jaren 2014-2017 lagen ze gemiddeld op ongeveer 5 euro en 15 euro per ha. Voor actuele informatie over het SNL wordt verwezen naar de website van BIJ12, een uitvoeringsorganisatie voor de twaalf provincies (www.bij12.nl).

De overige subsidies - 14 euro per ha in 2018 - zijn afkomstig van verschillende verstrekkers en hebben geen structureel karakter.

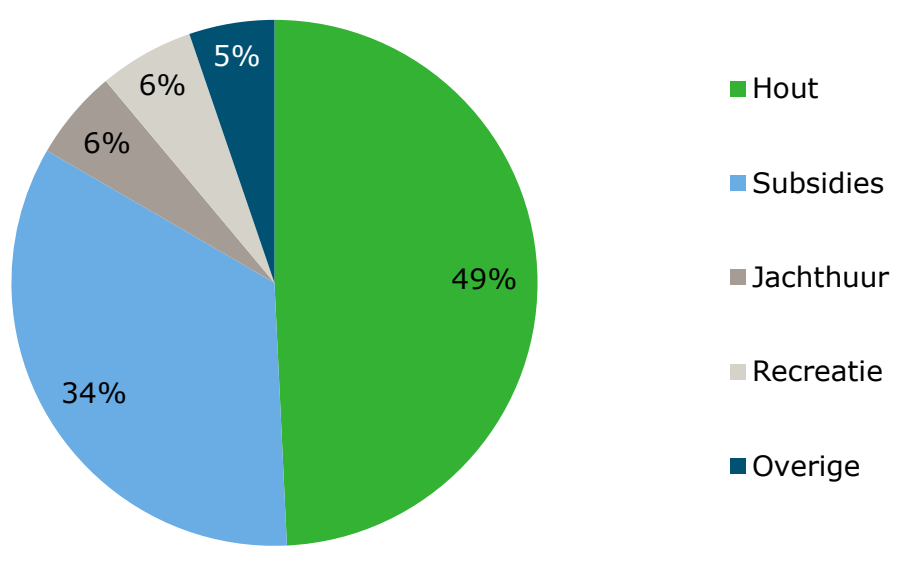

Figuur 1.1 Verdeling (\%) van de opbrengsten, 2018

Bron: Bedrijveninformatienet, Wageningen Economic Research.

\section{Overige opbrengsten constant}

De overige opbrengstenposten (jachthuur, recreatie en overig) brachten in 2018 gemiddeld 48 euro per ha op, ofwel $17 \%$ van de totale opbrengsten. De omvang van deze overige opbrengstenposten is door de jaren over het algemeen vrij stabiel.

\subsection{Houtprijs en oogstvolume}

\section{Houtprijs omhoog}

In 2018 is de gemiddelde gewogen houtprijs met 6\% (ten opzichte van 2017) gestegen tot ruim 41 euro per $\mathrm{m}^{3}$ (tabel 1.3). De gemiddelde houtprijs bereikte in 2016 een piek met 42 euro per $\mathrm{m}^{3}$ per ha. In 2018 lag de prijs 7\% hoger dan het gemiddelde prijsniveau in 2014-2017. 
Tabel 1.3 Opbrengstprijzen (euro per $\mathrm{m}^{3}$ ) van verkocht hout naar verkoopwijze, 2014-2018

\begin{tabular}{llllll} 
& 2014 & 2015 & 2016 & 2017 & 2018 \\
Op stam & 35,46 & 37,51 & 41,40 & 38,23 & 41,39 \\
\hline Geveld & 65,59 & 52,18 & 63,09 & 61,37 & 44,10 \\
\hline Gemiddeld & 36,41 & 37,96 & 42,36 & 38,94 & 41,46 \\
\hline
\end{tabular}

Bron: Bedrijveninformatienet, Wageningen Economic Research.

\section{Meer hout geoogst}

In 2018 is gemiddeld 3,25 $\mathrm{m}^{3}$ hout per ha bos geoogst (tabel 1.4); dat is $7 \%$ meer dan in de twee voorgaande jaren. Omdat vrijwel al het hout op stam wordt verkocht zijn de hiervoor genoemde gemiddelde houtprijzen (en totaalregel in tabel 1.3) praktisch gelijk aan de prijzen voor hout op stam.

Tabel 1.4 Volume van de houtverkopen ( $m^{3}$ per ha) naar verkoopwijze, 2014-2018

\begin{tabular}{lrrrrr} 
& 2014 & 2015 & 2016 & 2017 & 2,18 \\
Op stam & 3,42 & 3,04 & 2,83 & 3,17 \\
\hline Geveld & 0,12 & 0,15 & 0,19 & 0,09 & 0,08 \\
\hline Gemiddeld & 3,54 & 3,19 & 3,02 & 3,03 & 3,25 \\
\hline
\end{tabular}

Bron: Bedrijveninformatienet, Wageningen Economic Research.

Een klein deel van de houtopbrengsten bestaat uit de verkoop van hout als biomassa (stookhout). Het ging daarbij in de afgelopen vijf jaar om een jaarlijks bedrag van gemiddeld 8 euro per ha bos. Vanaf 2012 wordt ook het volume van deze houtverkopen opgevraagd en/of geschat. Dit volume is toegenomen van gemiddeld $0,32 \mathrm{~m}^{3}$ per jaar in de jaren $2014-2016$ tot $0,51 \mathrm{~m}^{3}$ per ha per jaar in 2017-2018.

\subsection{Kostensoorten}

Gemiddelde kosten iets lager De gemiddelde kosten van het bosbeheer van de particuliere bosbedrijven (met meer dan 50 ha bos) zijn in 2018 uitgekomen op 268 euro per ha, iets minder dan in 2017 (tabel 1.5).

Tabel 1.5 Kosten (euro per ha bos) naar kostensoorten, 2014-2018

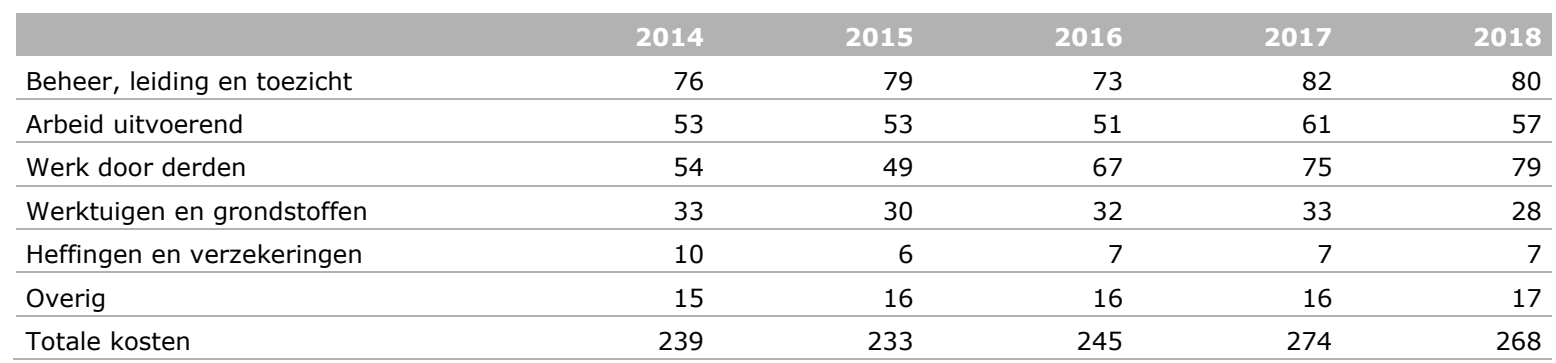

Bron: Bedrijveninformatienet, Wageningen Economic Research.

De kosten van het personeel voor het uitvoerende werk (post 'arbeid uitvoerend') en werktuigen en grondstoffen daalden ten opzichte van 2017, maar de kosten voor uitbesteed werk (werk door derden) namen toe. Het werk door derden is nu samen met post 'beheer, leiding en toezicht' de belangrijkste kostenpost, met respectievelijk $29 \%$ en $30 \%$ van de kosten (figuur 1.2). Hierna volgen de posten arbeid uitvoerend $(21 \%)$, werktuigen en grondstoffen $(10 \%)$, heffingen en verzekeringen $(3 \%)$ en overige kosten (7\%). 


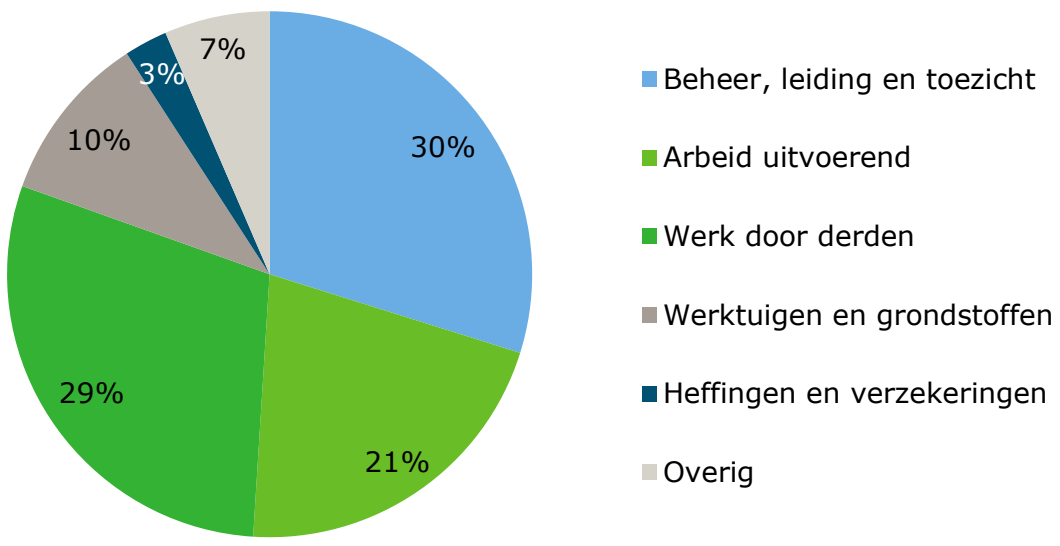

Figuur 1.2 Verdeling (\%) kosten naar kostensoorten, 2018

Bron: Bedrijveninformatienet, Wageningen Economic Research.

Een deel van het werk wordt door de eigenaar zelf uitgevoerd waarvoor een 'berekend loon' is opgenomen. In 2018 is daarvoor gemiddeld 13 euro per ha bos in rekening gebracht, ofwel 5\% van de totale kosten van het bosbeheer.

\section{$1.5 \quad$ Kostenplaatsen}

Aandeel algemene kosten op 39\%

De diverse kostensoorten worden toegerekend aan maatregelen of activiteiten: kostenplaatsen. De grootste post wordt gevormd door algemene kosten. In 2018 bedroegen de algemene kosten 105 euro per ha, licht boven het gemiddelde niveau in de jaren 2014-2017 (tabel 1.6). Ongeveer driekwart van de algemene kosten wordt gevormd door beheer, leiding en toezicht. Daarnaast bestaan de algemene kosten uit heffingen en verzekeringen en overige kosten (zoals voor administratieve dienstverlening).

Tabel 1.6 Kosten (euro per ha bos) naar kostenplaatsen, 2014-2018

\begin{tabular}{|c|c|c|c|c|c|}
\hline & 2014 & 2015 & 2016 & 2017 & 2018 \\
\hline Algemene kosten & 100 & 101 & 96 & 106 & 105 \\
\hline w.v. Beheer, leiding en toezicht & 76 & 79 & 73 & 82 & 80 \\
\hline Overig & 15 & 16 & 16 & 16 & 18 \\
\hline Bosverjonging & 19 & 20 & 22 & 25 & 16 \\
\hline Infrastructuur & 30 & 28 & 29 & 35 & 32 \\
\hline Vellingen & 17 & 15 & 27 & 27 & 37 \\
\hline Totaal & 239 & 233 & 245 & 274 & 268 \\
\hline
\end{tabular}

Bron: Bedrijveninformatienet, Wageningen Economic Research.

In 2018 lagen de totale kosten voor bosverjonging, onderhoud van infrastructuur en overig bosonderhoud op 125 euro per ha. Dat is minder dan de 141 euro per ha in 2017, maar ongeveer gelijk aan het gemiddelde in de periode 2014-2016. De kosten voor de houtoogst in eigen beheer lagen in 2018 op 37 euro per ha (tabel 1.6), ruim boven het gemiddelde in de voorgaande jaren (gemiddeld 22 euro per ha in de periode 2014-2017). 


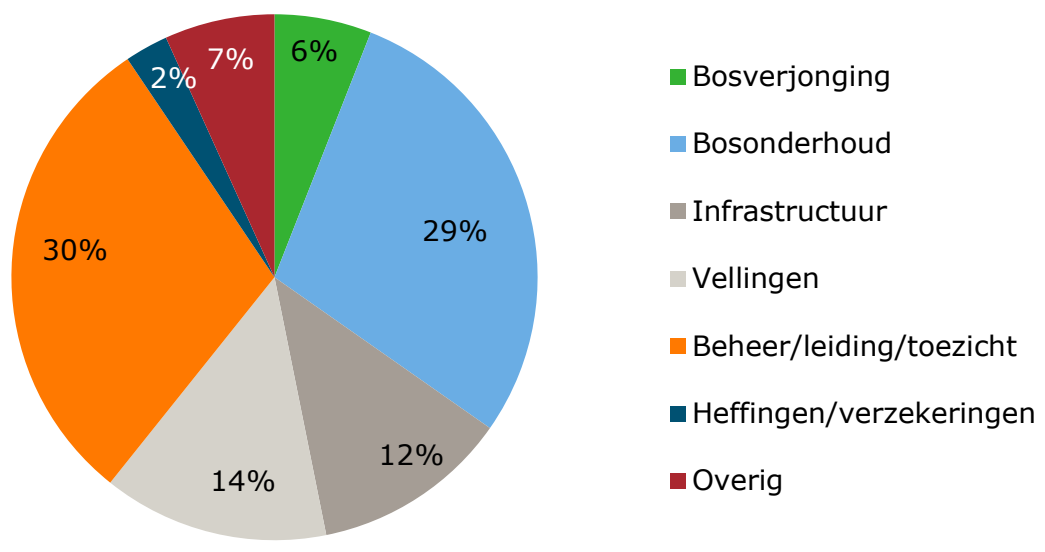

Figuur 1.3 Verdeling (\%) kosten naar kostenplaatsen, 2018 Bron: Bedrijveninformatienet, Wageningen Economic Research.

De kostenplaatsen Beheer/leiding/toezicht en Bosonderhoud hebben de grootste aandelen in de totale kosten (figuur 1.3).

\subsection{Spreiding in resultaten}

De resultaten van de bosbedrijven vertonen grote verschillen. In 2018 had 33\% van de bedrijven een bedrijfsresultaat van minder dan -100 euro per ha, en $30 \%$ een resultaat van meer dan 100 euro per ha (tabel 1.7).

Tabel 1.7 Verdeling (\%) bedrijven en areaal bos naar bedrijfsresultaat, 2016-2018

\begin{tabular}{|c|c|c|c|c|c|c|}
\hline \multirow{2}{*}{$\begin{array}{l}\text { Bedrijfsresultaat } \\
\text { (euro/ha bos) }\end{array}$} & \multicolumn{2}{|c|}{2016} & \multicolumn{2}{|c|}{2017} & \multicolumn{2}{|c|}{2018} \\
\hline & Aantal & Ha bos & Aantal & Ha bos & Aantal & Ha bos \\
\hline-100 tot -50 & 5 & 12 & 13 & 15 & 9 & 6 \\
\hline-50 tot 0 & 15 & 23 & 5 & 8 & 9 & 14 \\
\hline 50 tot 100 & 6 & 9 & 8 & 15 & 7 & 5 \\
\hline$>100$ & 32 & 29 & 23 & 22 & 30 & 25 \\
\hline Totaal & 100 & 100 & 100 & 100 & 100 & 100 \\
\hline
\end{tabular}

Bron: Bedrijveninformatienet, Wageningen Economic Research.

Gemiddeld heeft 50\% van de bedrijven in de periode 2016-2018 een positief resultaat behaald. De bedrijven die uit de rode cijfers bleven, beheerden gemiddeld 53\% van het bosareaal. 


\section{Resultaten naar bedrijfsgrootte}

\subsection{Bedrijfsresultaten}

Middelgrote en grote bedrijven boeken hogere resultaten

Om een beeld te geven van de resultaten naar de grootte van het bosbezit zijn drie klassen bedrijven onderscheiden: kleine (van 50 tot $100 \mathrm{ha}$ ), middelgrote (100 tot $250 \mathrm{ha}$ ) en grote (250 ha bos of meer). De kleine bedrijven hebben in 2018 een negatief resultaat van 13 euro geboekt en de middelgrote en grote bedrijven een positief resultaat van rond 30 euro per ha bos (tabel 2.1).

De verhouding tussen de opbrengsten en kosten in procenten (een andere maat voor de rentabiliteit) varieerde tussen $95 \%$ op de kleine bedrijven tot rond de $110 \%$ op de middelgrote en grote bedrijven.

Ten opzichte van de gemiddelde resultaten in de vier voorgaande jaren (2014-2017), is het verlies op de kleine bedrijven in 2018 teruggebracht door lagere kosten (tabel 2.1). Op de middelgrote en grote bedrijven is het resultaat in 2018 lager uitgevallen door hogere kosten. Het inkomen uit het bosbedrijf - het bedrijfsresultaat plus de berekende vergoeding van de eigen arbeid - is op de kleine bedrijven gestegen tot 21 euro per ha bos in 2018, tegenover een verlies van 5 euro per ha in de voorafgaande 2014-2017 (tabel 2.1).

Tabel 2.1 Resultaten (euro per ha bos per jaar) naar grootte bosareaal, 2014-2018

\begin{tabular}{lrr|r|r|r} 
& \multicolumn{2}{c}{50 tot 100 ha } & \multicolumn{1}{c}{100 tot 250 ha } & 250 ha of meer \\
\cline { 2 - 7 } Opbrengsten & $2014 / 2017$ & 2018 & $2014 / 2017$ & 2018 & $2014 / 2017$ \\
\hline Kosten & 251 & 250 & 338 & 342 & 255 \\
\hline Bedrijfsresultaat & 283 & 263 & 287 & 312 & 219 \\
\hline Opbrengsten/kosten (\%) & -33 & -13 & 51 & 29 & 36 \\
\hline Inkomen uit het bosbedrijf & 92 & 95 & 118 & 109 & 117 \\
\hline
\end{tabular}

Bron: Informatienet, Wageningen Economic Research.

De middelgrote bedrijven behalen een hoger inkomen per ha dan de grote bedrijven doordat de inbreng van eigen arbeid (per ha) er hoger is. Op de middelgrote bedrijven lag die in 2018 op $6 \%$ van de totale kosten, tussen de $1 \%$ op de grote en $13 \%$ op de kleine bedrijven.

Spreiding bedrijfsresultaten groot

Over het algemeen lopen de bedrijfsresultaten op bij een toenemende bedrijfsomvang (ha bos) (figuur 2.1): in de periode 2014-2018 boekte gemiddeld 49\% van de kleine bedrijven een positief resultaat. Voor de middelgrote bedrijven was dat $55 \%$, voor de grote bedrijven $61 \%$. 


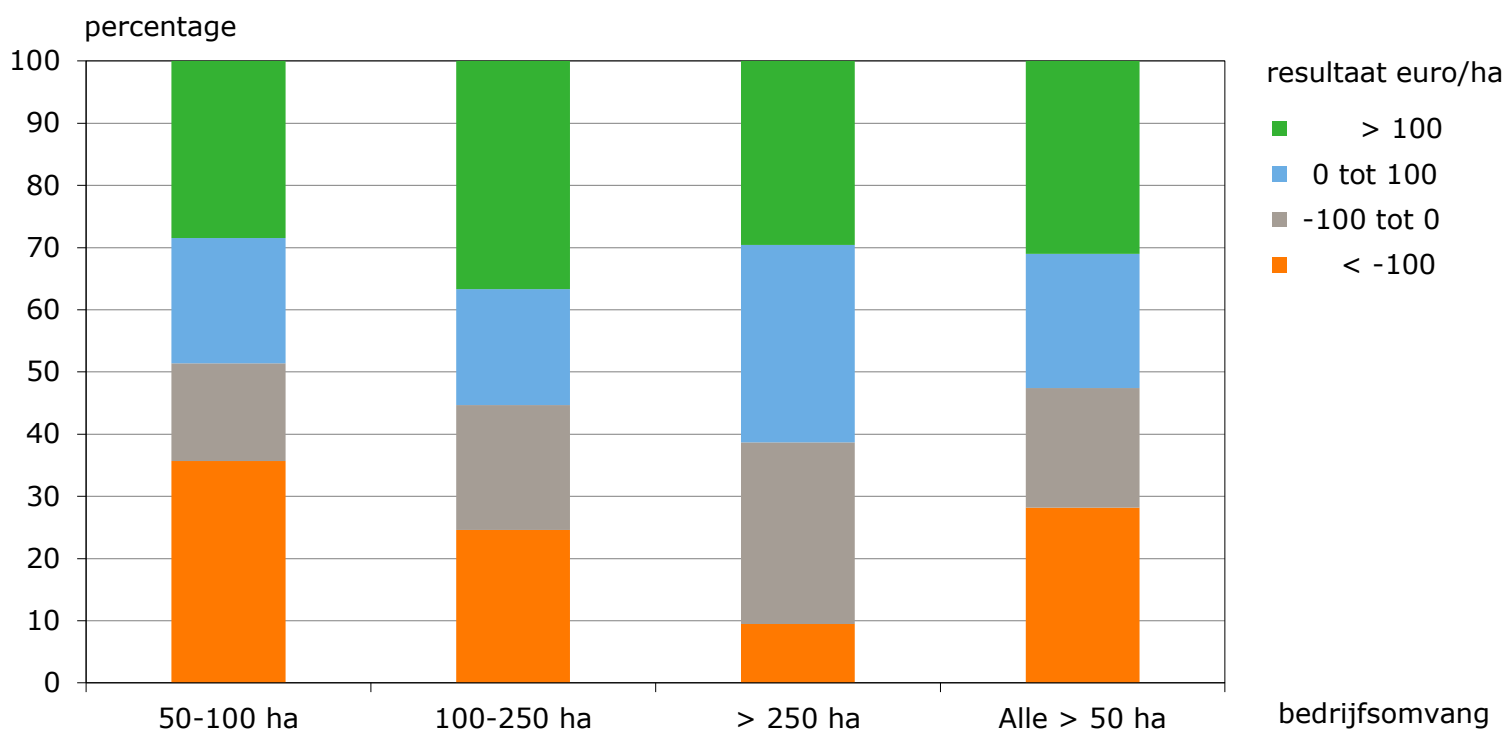

Figuur 2.1 Aandeel (\%) bedrijven naar bedrijfsresultaat en bedrijfsomvang, gemiddelde 2014-2018 Bron: Bedrijveninformatienet, Wageningen Economic Research.

\subsection{Opbrengsten}

Kleine bedrijven boekten laagste opbrengsten per ha

De kleine bedrijven boeken lagere opbrengsten per ha dan de middelgrote en grote bedrijven. De totale opbrengsten op de kleine bedrijven (50-100 ha bos) kwamen in 2018 uit op 250 euro per ha, gelijk aan het gemiddelde niveau in de periode 2014-2017 (tabel 2.2). Tegenover een vrij sterke afname van de subsidies stonden meer overige opbrengsten en houtopbrengsten. In 2018 bestonden de opbrengsten van de kleine bedrijven voor de helft uit houtopbrengsten, $30 \%$ uit subsidies en voor $20 \%$ uit andere opbrengsten (jachthuur, recreatie- en overige opbrengsten).

Middelgrote bedrijven ontvingen hoogste subsidies per ha

De opbrengsten van de middelgrote bedrijven waren in 2018 vrijwel gelijk aan het gemiddelde in de vier voorgaande jaren (2014-2017). De totale subsidies - die veel hoger liggen dan op de twee andere groepen bedrijven - namen in 2018 toe. Daar stonden wat lagere houtopbrengsten en andere opbrengsten tegenover. Het aandeel van de subsidies is op de middelgrote bedrijven in 2018 uitgekomen op 46\% (tegen 40\% gemiddeld in de jaren 2014-2017); de houtopbrengsten waren goed voor $39 \%$ van de opbrengsten, en de andere opbrengsten voor $15 \%$.

Tabel 2.2 Opbrengsten (euro per ha bos per jaar) naar grootte bosareaal, 2014-2018

\begin{tabular}{|c|c|c|c|c|c|c|}
\hline & \multicolumn{2}{|c|}{50 tot 100 ha } & \multicolumn{2}{|c|}{100 tot $250 \mathrm{ha}$} & \multicolumn{2}{|c|}{250 ha of meer } \\
\hline & $2014 / 2017$ & 2018 & $2014 / 2017$ & 2018 & $2014 / 2017$ & 2018 \\
\hline Hout & 120 & 126 & 145 & 132 & 131 & 153 \\
\hline Geveld & 6 & 5 & 4 & 0 & 11 & 5 \\
\hline Beheersubsidie & 80 & 70 & 105 & 117 & 66 & 76 \\
\hline Jachthuur & 11 & 10 & 16 & 17 & 20 & 18 \\
\hline Recreatie & 20 & 21 & 21 & 27 & 10 & 11 \\
\hline Overig & 6 & 18 & 22 & 9 & 14 & 16 \\
\hline Totaal & 251 & 250 & 338 & 342 & 255 & 281 \\
\hline
\end{tabular}

Bron: Informatienet, Wageningen Economic Research. 


\section{Grote bedrijven verhoogden opbrengsten}

De grote bedrijven zagen hun opbrengsten in 2018 met $10 \%$ stijgen ten opzichte van het gemiddelde in de periode 2014-2017 tot 281 euro per ha (tabel 2.2). Dat is in hoofdzaak te danken aan de hogere houtopbrengsten. In 2018 bestonden de opbrengsten op de grote bedrijven voor 54\% uit houtopbrengsten, voor $30 \%$ uit subsidies en voor $16 \%$ uit andere opbrengsten (jachthuur, recreatieen overige opbrengsten).

\section{$2.3 \quad$ Kosten}

\section{Kleine bedrijven drukten kosten}

De kosten op de kleine bedrijven zijn in 2018 uitgekomen op 263 euro per ha (tabel 2.3), 7\% lager dan het gemiddelde niveau in de jaren 2014-2017. De kosten voor het uitvoerende werk ('arbeid uitvoerend') werden teruggebracht. Samen met de kosten van het terreinbeheer door derden ('werk door derden') vormden ze $49 \%$ van de totale kosten in 2018. De post beheer, leiding en toezicht was goed voor $27 \%$, en de overige posten (werktuigen en grondstoffen, heffingen en verzekeringen en overige kosten) waren goed voor $24 \%$.

\section{Middelgrote bedrijven maakten meer kosten}

Op de middelgrote bedrijven zijn de kosten in 2018 (ten opzichte van de gemiddelde kosten in 20142017) met 9\% gestegen tot 312 euro per ha (tabel 2.3). De kosten van het terreinbeheer door derden en die van het eigen personeel stegen. Deze twee posten waren in 2018 goed voor $46 \%$ van de totale kosten; $34 \%$ ging op aan beheer, leiding en toezicht en $20 \%$ aan de overige kostenposten.

Tabel 2.3 Kosten (euro per ha bos per jaar) naar kostensoorten en grootte bosareaal, 2014-2018

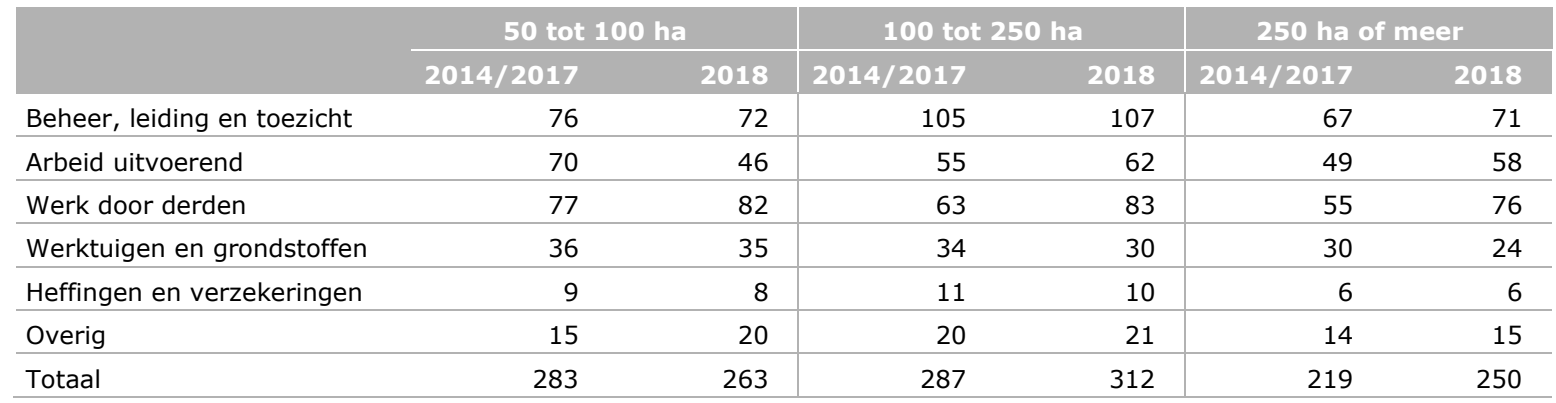

Bron: Bedrijveninformatienet, Wageningen Economic Research.

Grote bedrijven maakten ook meer kosten

Ook op de grote bedrijven namen de totale kosten toe, met 14\% tot 250 euro per ha in 2018

(tabel 2.3). De hogere kosten (ten opzichte van die in de periode 2014-2017) bestaan net zoals op de middelgrote bedrijven uit 'werk door derden' en 'arbeid uitvoerend'. Samen waren deze posten in 2018 goed voor 54\% van de kosten. De post beheer, leiding en toezicht volgde met een aandeel van $28 \%$; de overige kostenposten namen $18 \%$ van de kosten in. De grote bedrijven geven absoluut en relatief meer uit aan personeel dan de kleine en middelgrote bedrijven. Maar daardoor maken ze minder kosten voor de inhuur van derden, waaronder bijvoorbeeld een rentmeester, bosgroep of ingenieursbureau. Een deel van deze kosten valt onder de post beheer, leiding en toezicht.

\section{Weinig verandering in algemene kosten}

In termen van kostenplaatsen lagen de algemene kosten per ha met een aandeel van $45 \%$ in 2018 het hoogst op de middelgrote bedrijven. Op de drie groepen bedrijven veranderden de algemene kosten in 2018 weinig ten opzichte van het gemiddelde van de voorgaande jaren (tabel 2.4). Op de kleinere bedrijven stegen de kosten voor de houtoogst in eigen beheer ('vellingen'), terwijl de kosten voor het overige bosbeheer (bosverjonging, bosonderhoud en infrastructuur) lager uitvielen. Op de middelgrote en grote bedrijven namen zowel de kosten voor vellingen als die voor het bosbeheer toe. 
Tabel 2.4 Kosten (euro per ha bos per jaar) naar kostenplaatsen en grootte bosareaal, 2014-2018

\begin{tabular}{|c|c|c|c|c|c|c|}
\hline & \multicolumn{2}{|c|}{50 tot 100 ha } & \multicolumn{2}{|c|}{100 tot 250 ha } & \multicolumn{2}{|c|}{250 ha of meer } \\
\hline & $2014 / / 17$ & 2018 & $2014 / / 17$ & 2018 & $2014 / / 17$ & 2018 \\
\hline Algemene kosten & 100 & 100 & 136 & 141 & 87 & 91 \\
\hline Heffingen en verzekeringen & 9 & 8 & 11 & 10 & 6 & 6 \\
\hline Overig & 15 & 20 & 20 & 24 & 14 & 15 \\
\hline Bosonderhoud & 98 & 76 & 74 & 93 & 65 & 70 \\
\hline Infrastructuur & 40 & 26 & 30 & 34 & 28 & 34 \\
\hline Vellingen & 26 & 50 & 24 & 31 & 19 & 35 \\
\hline Totaal & 283 & 263 & 287 & 312 & 219 & 250 \\
\hline
\end{tabular}

Bron: Bedrijveninformatienet, Wageningen Economic Research.

De kosten van de kleine bedrijven bestonden in 2018 voor $19 \%$ uit vellingkosten. Op de middelgrote en grote bedrijven waren de aandelen van de vellingkosten respectievelijk $10 \%$ en $14 \%$. 


\section{$3 \quad$ Resultaten naar regio}

\subsection{Bedrijfsresultaten}

Bedrijfsresultaat in Centrum daalde fors

In de regio's Noordoost en Zuid (zie bijlage 1, figuur B1.1) waren de bedrijfsresultaten van respectievelijk 31 euro en 25 euro per ha in 2018 een verbetering ten opzichte van het gemiddelde in de jaren 2014-2017 (tabel 3.1). In beide regio's stegen de opbrengsten harder dan de kosten: de opbrengsten-kostenverhouding kwam in de regio Noordoost uit op $110 \%$ en in Zuid op $114 \%$. In de regio Centrum liep het bedrijfsresultaat echter vrij sterk terug van 35 tot 7 euro per ha en daalde de rentabiliteit van $114 \%$ naar $102 \%$.

Tabel 3.1 Resultaten (euro per ha bos per jaar) naar regio, 2014-2018

\begin{tabular}{|c|c|c|c|c|c|c|}
\hline & \multicolumn{2}{|c|}{ Noordoost } & \multicolumn{2}{|c|}{ Centrum } & \multicolumn{2}{|c|}{ Zuid } \\
\hline & $2014 / / 17$ & 2018 & $2014 / / 17$ & 2018 & $2014 / / 17$ & 2018 \\
\hline Opbrengsten & 293 & 330 & 316 & 295 & 188 & 211 \\
\hline Bedrijfsresultaat & 23 & 31 & 35 & 7 & 18 & 25 \\
\hline Opbrengsten/kosten (\%) & 109 & 110 & 114 & 102 & 110 & 114 \\
\hline
\end{tabular}

Bron: Bedrijveninformatienet, Wageningen Economic Research.

In Noordoost hoogste inkomen: 51 euro per ha

In de regio Noordoost steeg het inkomen uit het bosbedrijf - het bedrijfsresultaat plus de berekende vergoeding van de eigen arbeid - tot 51 euro per ha in 2018, en in Zuid tot 37 euro per ha (tabel 3.1). In de regio Centrum nam het inkomen af tot 13 euro per ha. Op de bedrijven in de regio Noordoost is de inbreng van eigen arbeid (per ha) van de boseigenaar hoger dan in de andere regio's. De hiervoor in rekening gebrachte bedragen lagen op bedrijven in Noordoost in 2018 op $6 \%$ van de totale kosten, tegen $5 \%$ op de bedrijven in Zuid en $2 \%$ op de bedrijven in de regio Centrum.

\subsection{Opbrengsten}

Noordoost: aandeel houtopbrengsten 52\%

In de regio Noordoost waren de opbrengsten 330 euro per ha in 2018 (tabel 3.2), 13\% hoger dan de gemiddelde jaaropbrengst in de periode 2014-2017. Dat was vooral te danken aan hogere houtopbrengsten, en in minder mate aan hogere subsidies. In 2018 bestonden de opbrengsten op de bedrijven in Noordoost voor 52\% uit houtopbrengsten, voor $34 \%$ uit opbrengsten uit subsidies en voor $14 \%$ uit andere opbrengsten (jachthuur, recreatie- en overige opbrengsten).

\section{Centrum: aandeel houtopbrengsten $47 \%$}

De opbrengsten op de bedrijven in de regio Centrum zijn in 2018 ten opzichte van het gemiddelde in de jaren 2014-2017 met 7\% gedaald tot 295 euro per ha (tabel 3.2). Dat is te wijten aan lagere houtopbrengsten en subsidies. De houtopbrengsten waren in 2018 goed voor $47 \%$ van de totale opbrengsten, de subsidies voor $34 \%$ en de andere opbrengsten voor $19 \%$. 
Tabel 3.2 Opbrengsten (euro per ha bos per jaar) naar regio, 2014-2018

\begin{tabular}{|c|c|c|c|c|c|c|}
\hline & \multicolumn{2}{|c|}{ Noordoost } & \multicolumn{2}{|c|}{ Centrum } & \multicolumn{2}{|c|}{ Zuid } \\
\hline & $2014 / / 17$ & 2018 & $2014 / / 17$ & 2018 & $2014 / / 17$ & 2018 \\
\hline Hout & 140 & 173 & 159 & 139 & 85 & 94 \\
\hline Geveld & 14 & 8 & 5 & 2 & 3 & 0 \\
\hline Beheersubsidie & 78 & 84 & 91 & 96 & 62 & 70 \\
\hline Jachthuur & 10 & 10 & 29 & 28 & 16 & 10 \\
\hline Recreatie & 16 & 17 & 7 & 11 & 20 & 25 \\
\hline Overig & 24 & 18 & 12 & 16 & 2 & 10 \\
\hline Totaal & 293 & 330 & 316 & 295 & 188 & 211 \\
\hline
\end{tabular}

Bron: Informatienet, Wageningen Economic Research.

Zuid: aandeel houtopbrengsten $45 \%$

In de regio Zuid stegen de opbrengsten tot 211 euro per ha in 2018, 12\% hoger dan het gemiddelde van 2014-2017 (tabel 3.2). De totale opbrengsten bestonden in 2018 voor $45 \%$ uit houtopbrengsten, voor $34 \%$ uit subsidies en voor $21 \%$ uit andere opbrengsten.

\subsection{Kosten}

Noordoost: kosten beheer, leiding en toezicht stegen naar 87 euro per ha

De kosten op de bedrijven in de regio Noordoost zijn in 2018 uitgekomen op 299 euro per ha (tabel 3.3), 11\% lager dan het gemiddelde niveau in de jaren 2014-2017. Zowel de kosten voor beheer, leiding en toezicht, als voor het personeel voor het uitvoerende werk ('arbeid uitvoerend') als de kosten van het terreinbeheer door derden ('werk door derden') namen toe. De eerste post (beheer, leiding en toezicht) was in 2018 goed voor 29\% van de totale kosten; $51 \%$ ging naar de posten 'arbeid uitvoerend' en 'werk door derden', en $20 \%$ naar de overige posten (werktuigen en grondstoffen, heffingen en verzekeringen en overige kosten).

Centrum: kosten beheer, leiding en toezicht daalden naar 70 euro per ha In de regio Centrum lagen de kosten met 288 euro per ha in 2018 ongeveer op het niveau van het gemiddelde in de jaren 2014-2017 (tabel 3.3). De kosten van het terreinbeheer door derden stegen, terwijl de kosten personeel voor het uitvoerende werk daalden. Deze twee posten waren in 2018 goed voor $55 \%$ van de totale kosten; $24 \%$ ging op aan beheer, leiding en toezicht en $21 \%$ aan de overige kostenposten.

Tabel 3.3 Kosten (euro per ha bos per jaar) naar kostensoorten en regio, 2014-2018

\begin{tabular}{|c|c|c|c|c|c|c|}
\hline & \multicolumn{2}{|c|}{ Noordoost } & \multicolumn{2}{|c|}{ Centrum } & \multicolumn{2}{|c|}{ Zuid } \\
\hline & $2014 / / 17$ & 2018 & $2014 / / 17$ & 2018 & $2014 / / 17$ & 2018 \\
\hline Beheer, leiding en toezicht & 79 & 87 & 73 & 70 & 81 & 81 \\
\hline Werk door derden & 66 & 79 & 72 & 93 & 39 & 59 \\
\hline Werktuigen en grondstoffen & 37 & 33 & 36 & 32 & 19 & 13 \\
\hline Overig & 17 & 19 & 19 & 21 & 9 & 10 \\
\hline Totaal & 270 & 299 & 280 & 288 & 171 & 186 \\
\hline
\end{tabular}

Bron: Bedrijveninformatienet, Wageningen Economic Research.

Zuid: kosten beheer, leiding en toezicht stabiel op 81 euro per ha

De kosten op de bedrijven in regio Zuid stegen in 2018 met $9 \%$ tot 186 euro per ha (tabel 3.3). De hogere kosten (ten opzichte van die in de periode 2014-2017) zijn veroorzaakt door hogere kosten 
voor werk door derden. De totale kosten op de bedrijven in Zuid zijn veel lager dan in de andere twee regio's. In Zuid zijn relatief veel kosten gaan zitten in beheer, leiding en toezicht: 44\% van de totale kosten in 2018. De kosten van het terreinbeheer door derden en het eigen personeel waren goed voor $40 \%$, en de andere kosten samen voor $16 \%$.

Centrum investeert bovengemiddeld in bosonderhoud

De gemiddelde algemene kosten lopen in de drie regio's weinig uiteen. Dat geldt niet voor het bosonderhoud, dat in het Centrum gemiddeld 109 euro per ha vergde, tegen 64 euro per ha in Noordoost en 55 euro per ha in Zuid.

Tabel 3.4 Kosten (euro per ha bos per jaar) naar kostenplaatsen en regio, 2014-2018

\begin{tabular}{|c|c|c|c|c|c|c|}
\hline & \multicolumn{2}{|c|}{ Noordoost } & \multicolumn{2}{|c|}{ Centrum } & \multicolumn{2}{|c|}{ Zuid } \\
\hline & $2014 / / 17$ & 2018 & $2014 / / 17$ & 2018 & $2014 /{ }^{\prime} 17$ & 2018 \\
\hline Algemene kosten & 104 & 115 & 100 & 98 & 98 & 98 \\
\hline Heffingen en verzekeringen & 9 & 8 & 7 & 7 & 7 & 6 \\
\hline Overig & 17 & 20 & 20 & 21 & 9 & 11 \\
\hline Bosonderhoud & 67 & 64 & 103 & 109 & 46 & 55 \\
\hline Infrastructuur & 32 & 45 & 41 & 30 & 14 & 14 \\
\hline Vellingen & 34 & 57 & 18 & 30 & 5 & 14 \\
\hline Totaal & 270 & 299 & 280 & 288 & 171 & 186 \\
\hline
\end{tabular}

Bron: Bedrijveninformatienet, Wageningen Economic Research.

In Noordoost lagen de kosten voor de houtoogst in eigen beheer ('vellingen') in 2018 boven het gemiddelde niveau in de jaren 2014-2017, terwijl de kosten voor het overige bosbeheer (bosverjonging, bosonderhoud en infrastructuur) lager uitvielen. Ook in de regio Centrum stegen de vellingkosten, maar bleven de kosten voor het overig bosbeheer ongeveer gelijk. In de regio Zuid lagen zowel de vellingkosten als de kosten voor het overige bosbeheer in 2018 boven het gemiddelde in de periode 2014-2017. 


\section{$4 \quad$ Resultaten op lange termijn}

\subsection{Bedrijfsresultaten}

\section{Positieve trend}

De resultaten in dit hoofdstuk zijn gecorrigeerd voor inflatie (zie bijlage 1). Het gemiddeld reëel bedrijfsresultaat van particuliere bosbedrijven (groter dan 50 ha) laat over de gehele waarnemingsperiode van 1975-2018 een positieve trend zien (figuur 4.1). In de periode 1975-1990 was het gemiddelde resultaat 31 euro per ha negatief, maar werd het verlies sterk verminderd. In de jaren 1991-2005 - een meer stabiele periode - werd gemiddeld 22 euro verlies geleden. Vanaf 2006 zijn op twee jaar na alle jaren met een positief resultaat afgesloten; gemiddeld is tussen 2006 en 2018 een positief resultaat geboekt van 42 euro per ha bos.

Pieken en dalen

Verschillende factoren leiden tot pieken en dalen in het gemiddelde bedrijfsresultaat. In het stormjaar 1990 had de niet-geplande toename van het volume van de houtoogst eenmalig een hoger bedrijfsresultaat per ha tot gevolg. Ook in 1994 en 1995 was er een tijdelijke opleving door een hoger volume van de houtoogst. Toen maakten veel boseigenaren op het laatste moment nog gebruik van de aflopende herplantsubsidie. Nog rooskleuriger waren de resultaten in de jaren 2006-2007 en 20102015, vooral dankzij de hoge houtopbrengsten.

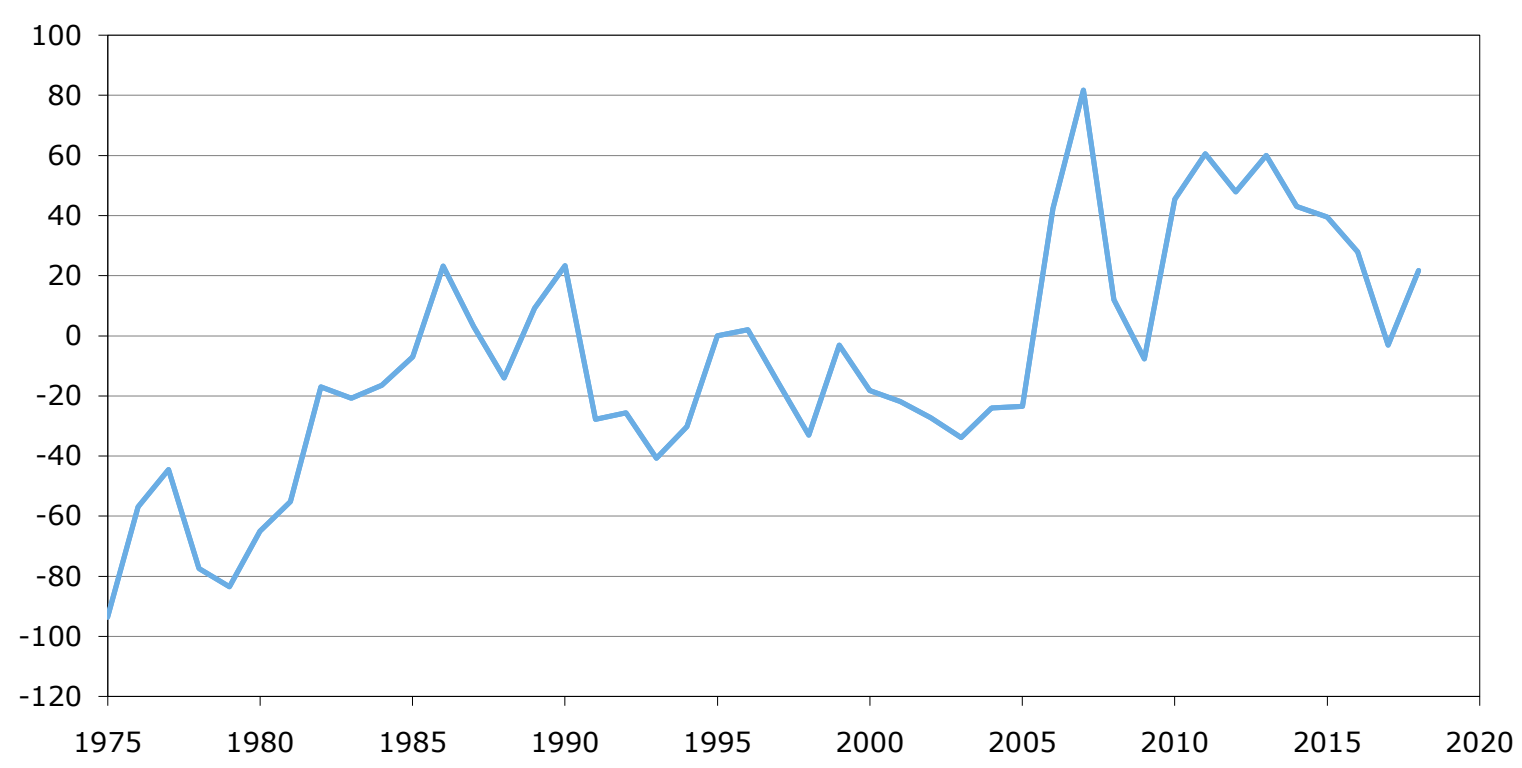

Figuur 4.1 Gemiddeld reëel bedrijfsresultaat per ha bos (in euro's van 2018), 1975-2018 Bron: CBS; Bedrijveninformatienet, Wageningen Economic Research.

\subsection{Kosten en opbrengsten}

Daling van kosten en opbrengsten

De bosbedrijven hebben de reële kosten in de afgelopen decennia met ongeveer $40 \%$ teruggedrongen, van gemiddeld 440 euro per ha per jaar tussen 1975-1980 tot 260 euro in de laatste vijf jaar. De grootste daling vond plaats vóór 1990. De ontwikkeling van de opbrengsten verliep tot 2005 volgens het patroon van de kosten; daarna stegen de houtopbrengsten onder invloed van de hogere houtprijzen. De totale reële opbrengsten lagen in de jaren 1975-1980 op gemiddeld ongeveer 
370 euro per ha per jaar en in de laatste vijf jaar op 285 euro per ha, bijna een vijfde lager. Tussen 2001 en 2005 werd een dieptepunt in opbrengsten bereikt van 230 euro per ha per jaar (figuur 4.2).

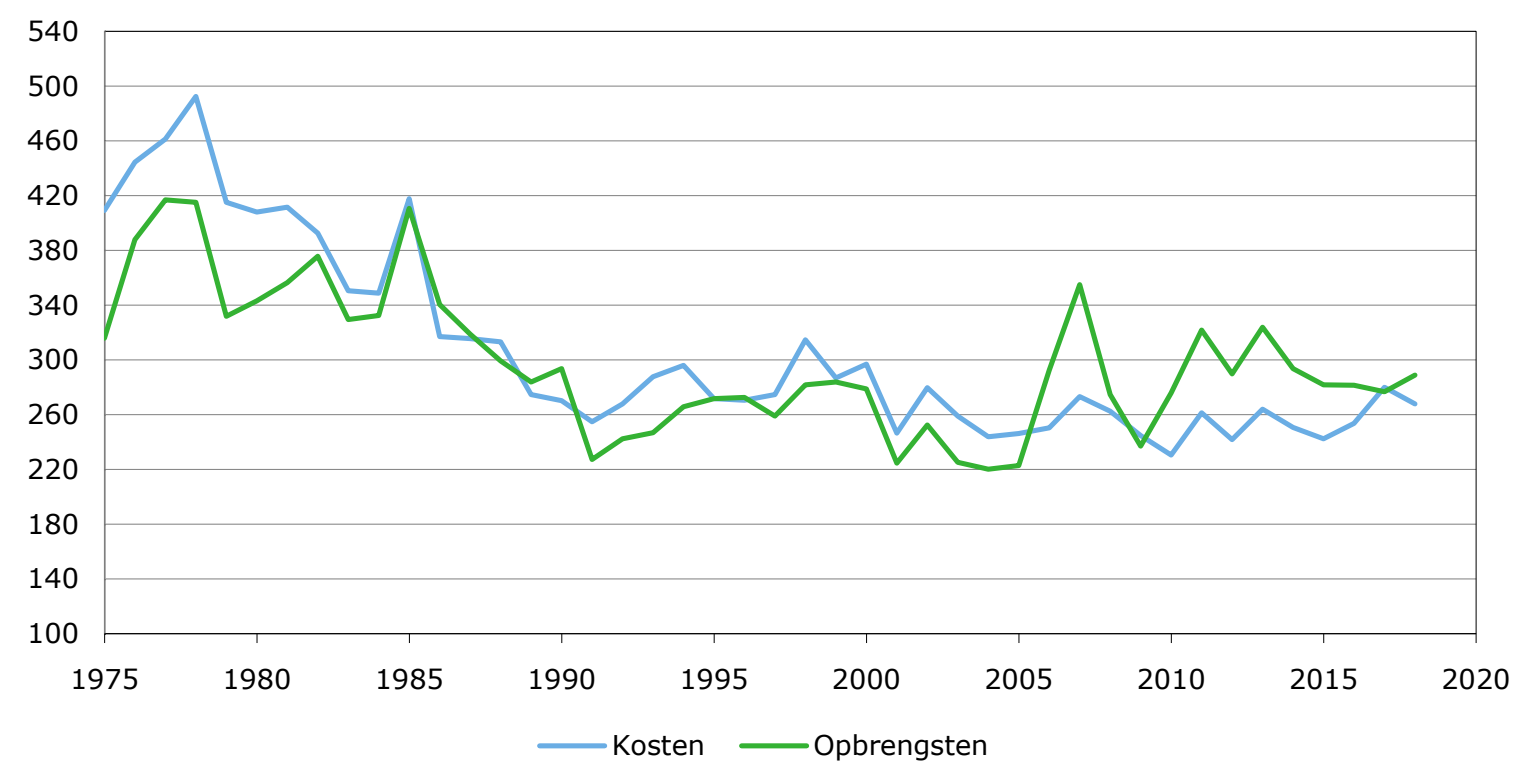

Figuur 4.2 Reële kosten en opbrengsten per ha bos (in euro's van 2018), 1975-2018 Bron: CBS; Bedrijveninformatienet, Wageningen Economic Research.

Herstel van houtopbrengsten na 2003-2005

De reële houtopbrengsten schommelden tot 1990 rond de 130 euro per ha per jaar, zakten tot minder dan 60 euro in de jaren 2003-2005, maar herstelden daarna tot gemiddeld 140 euro per jaar in de afgelopen vijf jaar. Door met voortschrijdende gemiddelden te werken worden de trends beter zichtbaar (figuur 4.3).

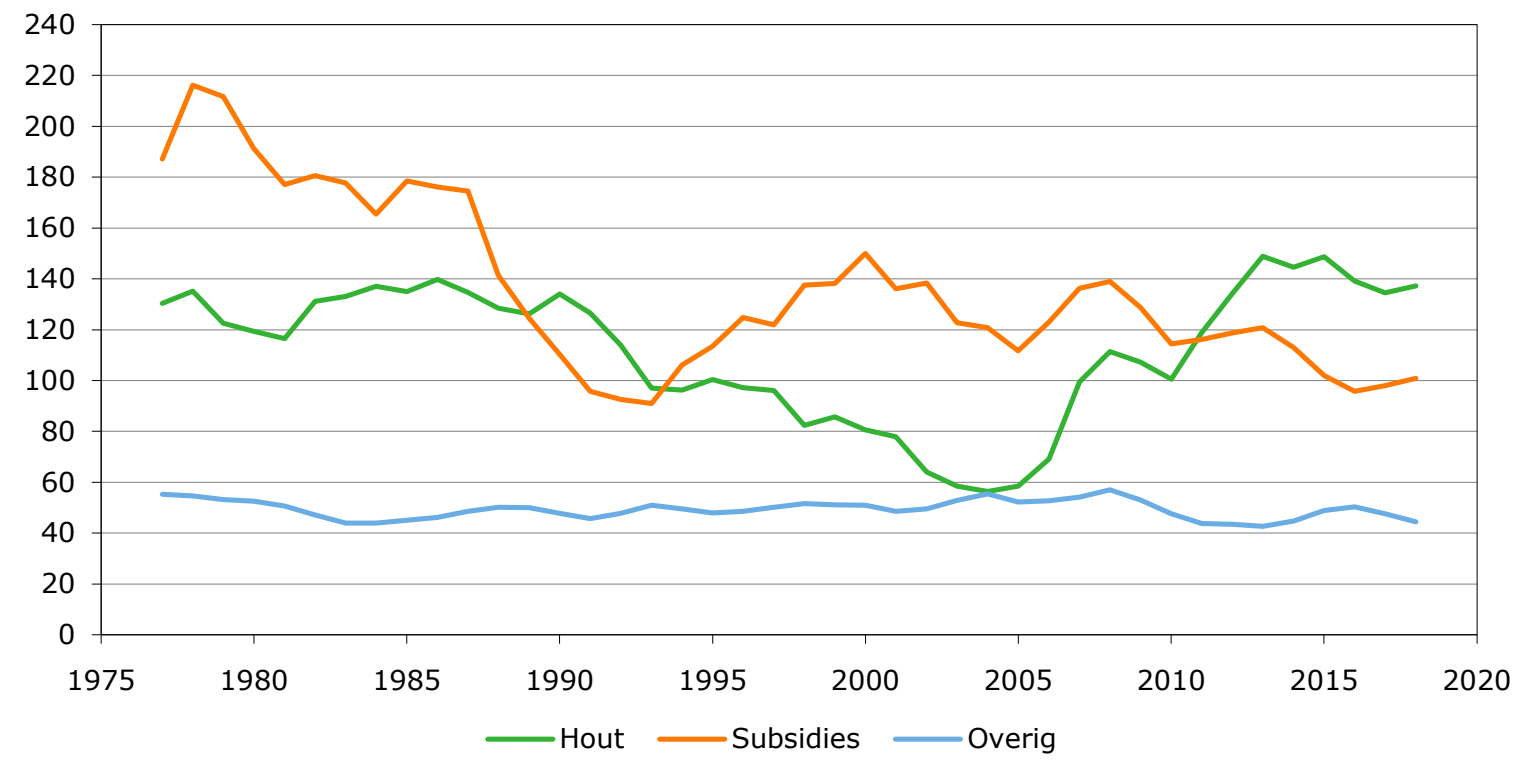

Figuur 4.3 Reële opbrengsten per ha bos (in euro's van 2018), voortschrijdend driejaarlijks gemiddelde 1977-2018

Bron: CBS; Bedrijveninformatienet, Wageningen Economic Research. 


\section{Wisselend verloop van subsidies}

Van de tweede helft van de jaren zeventig tot begin jaren negentig daalden de reële subsidies van circa 200 tot onder de 100 euro per ha bos per jaar (figuur 4.3). Daarna trad een gedeeltelijk herstel op tot rond de eeuwwisseling (140 euro). De piek rond de eeuwwisseling heeft onder meer te maken met de verstrekte subsidies in die periode op basis van de Regeling effectgerichte maatregelen in bossen en natuurterreinen (EGM), een instrument voor het uitvoeren van het Overlevingsplan Bos en Natuur (OBN). Daarnaast waren er ook wat meer incidentele bijdragen (overige subsidies) van andere overheden (zoals provincies). In de meest recente jaren zijn de subsidies rond de 100 euro per ha per jaar uitgekomen. De overige reële bedrijfsopbrengsten lagen in al die jaren tussen 40 en 60 euro per ha bos per jaar.

\subsection{Houtprijzen en oogstvolume}

In de periode 1990-2005 is de reële houtopbrengst gedaald (figuur 4.4) door zowel het lagere volume van de houtoogst (figuur 4.4) als de lagere gemiddelde prijs (figuur 4.5).

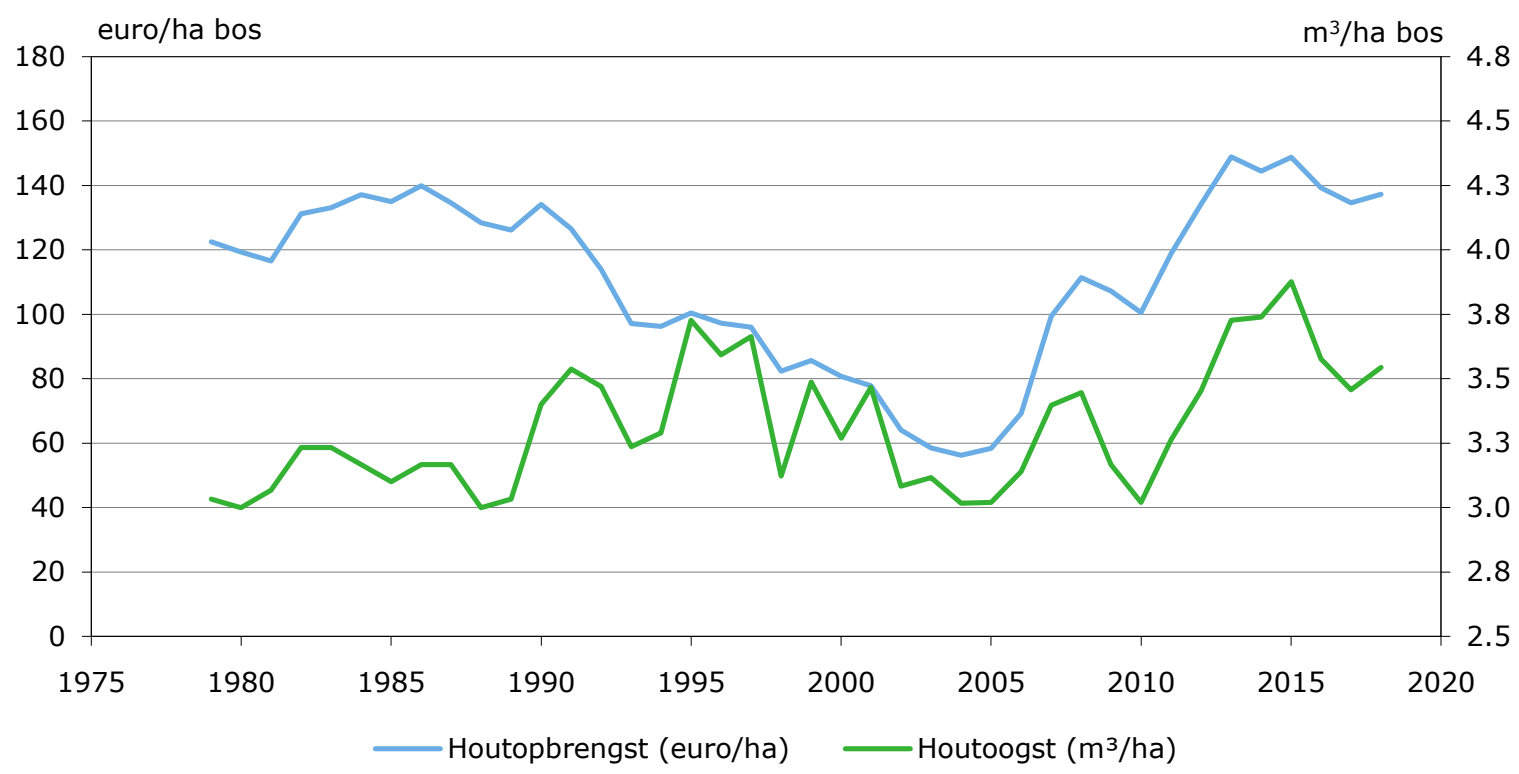

Figuur 4.4 Houtoogst ( $\mathrm{m}^{3}$ per ha) en reële houtopbrengsten per ha bos (in euro's van 2018), voortschrijdend driejaarlijks gemiddelde 1979-2018

Bron: CBS; Bedrijveninformatienet, Wageningen Economic Research.

Volume houtoogst zelden hoger dan $4 \mathrm{~m}^{3}$ per ha

Het volume van de houtoogst nam af van gemiddeld $3,5 \mathrm{~m}^{3}$ per ha in de eerste helft van de jaren negentig tot 3,0 $\mathrm{m}^{3}$ per ha in 2002. Dat hield verband met het wegvallen van de herplantsubsidie (per 1 januari 1994) en de sterke daling van de reële houtprijzen. De eindvelling verdween, terwijl dit niet werd gecompenseerd door meer dunning. Door het veranderde bosbeheer nam de houtvoorraad toe en verouderde de leeftijdsopbouw van het bos. Met de stijging van de houtprijzen na 2005 is het oogstvolume toegenomen tot gemiddeld 3,5 $\mathrm{m}^{3}$ per ha (2005-2018). Op de bosbedrijven is sinds 1975 slechts in enkele jaren meer geoogst dan $4 \mathrm{~m}^{3}$ per ha: 4,1 $\mathrm{m}^{3}$ in 1990 (stormjaar), 4,4 $\mathrm{m}^{3}$ in 1995 (aflopen herplantsubsidie), 4,1 $\mathrm{m}^{3}$ in 1999 en 4,2 $\mathrm{m}^{3}$ in 2013. Overigens zijn deze uitschieters niet te zien in figuur 4.4 doordat driejaarlijkse gemiddelden zijn weergegeven. 


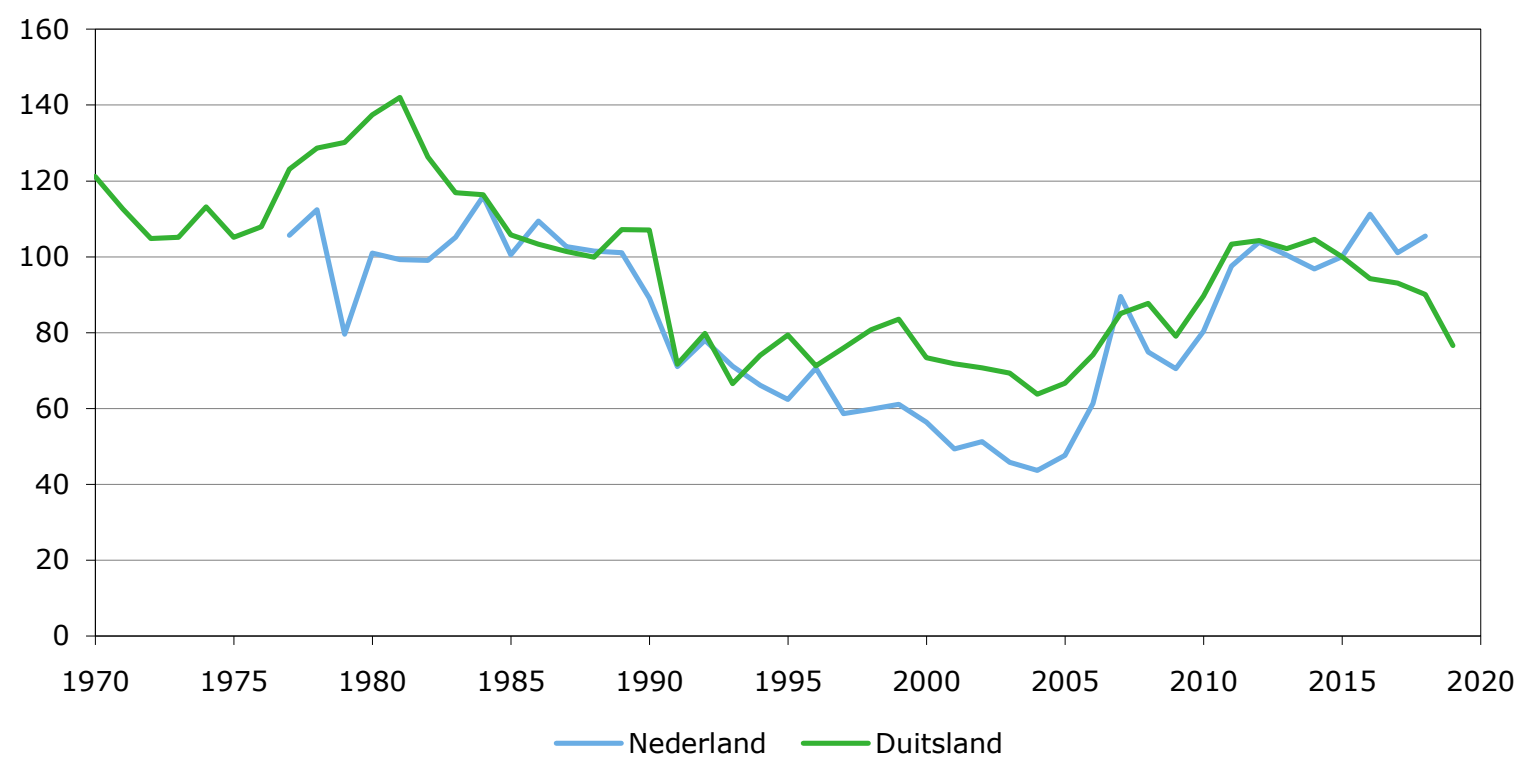

Figuur 4.5 Ontwikkeling reële houtprijs (2015=100), 1970-2019

De (geïndexeerde) houtprijs voor Nederland loopt tot 2018; die van Duitsland is ook beschikbaar voor 2019

Bron: OECD, Statistisches Bundesamt; Bedrijveninformatienet, Wageningen Economic Research.

Houtprijs internationaal bepaald

De gemiddelde reële houtprijs in Nederland daalde na de jaren tachtig sterk en bereikte een dieptepunt in 2004. Daarna steeg de prijs en was in 2010 terug op niveau van de jaren tachtig. In figuur 4.5 is de ontwikkeling van de reële houtprijs in Nederland (vanaf 1977) en het grote buurland en handelspartner Duitsland (vanaf 1970) weergegeven. De ontwikkelingen lopen in grote lijnen gelijk op, wat illustreert dat de houtmarkt internationaal is. 


\section{Literatuur en websites}

Jansen, P. en M. Vonk, 2007. Houtprijzen. In: Vakblad Natuur Bos Landschap 4 (2), p. 27.

Minister van Landbouw, Natuur en Voedselkwaliteit (LNV), 2019. Kamerstuk 33576, nr. 163.

Minister van LNV, 2020, Kamerbrief van 3 februari 2020, Ambities en doelen voor de Bossenstrategie.

OBV (Onderlinge Bossen Verzekeringen), 7 februari 2007. Forse schade voor Nederlandse bossen na januaristorm. Arnhem: Persbericht OBV. www.bossenverzekering.nl

OBV (Onderlinge Bossen Verzekeringen), 2011. Jaarverslag 2010. www.bossenverzekering.nl

PHN en LNV (Platform Hout Nederland) en ministerie van LNV, 2005. Multifunctionaliteit in balans. Visie op de houtoogst. Wageningen/Den Haag: PHN/LNV.

Poppe, K.J., 2004. Het Bedrijven-Informatienet van A tot Z. LEI Rapport 1.03.06, Den Haag.

Schelhaas, M., A.P.P.M. Clerkx, W.P. Daamen, J.F. Oldenburger, G. Velema, P. Schnitger, P. Schoonderwoerd en $\mathrm{H}$. Kramer, 2014. Zesde Nederlandse bosinventarisatie: methoden en basisresultaten (Alterra-rapport 2545). Wageningen.

\section{Websites}

www.agrimatie.nl

www.bij12.nl

www.cbs.nl

www.knbv.nl

www.oecd.org

www.probos.nl

www.vbne.nl

www.wur.nl 


\section{Bijlage 1 Verantwoording}

\section{B1.1 Doel en opzet monitor particuliere bosbouw}

Deze jaarlijkse publicatie over de Nederlandse particuliere bosbouw behandelt de resultaten, opbrengsten en kosten van bedrijven. Dit gebeurt onder meer ten behoeve van het beleid van de overheid (nationaal en regionaal), de Vereniging van Bos- en Natuurterreineigenaren (VBNE) en de eigenaren en beheerders van particuliere bosbedrijven.

In 2019 heeft de minister van Landbouw, Natuur en Voedselkwaliteit (LNV) een bossenstrategie aangekondigd (Kamerstuk 33576, nr. 163). In samenwerking met provincies wil de minister in 2020 een uitvoeringsprogramma van de strategie vaststellen om meer samenhang te brengen in het bossen-, natuur-, en klimaatbeleid (kamerbrief van 3 februari 2020). Een van de hoofdthema's wordt gevormd door de mogelijkheden van houtproductie in relatie tot vitaal bos. Biodiversiteit geldt als randvoorwaarde. Recreatie, beleving en educatie worden aangemerkt als belangrijke doelen, waarbij een lichte toename van de houtoogst mogelijk wordt geacht. Inzicht in de bedrijfseconomische aspecten van het bosbeheer is relevante informatie voor het beleid.

Het rapport beschrijft de gemiddelde bedrijfsresultaten van alle bedrijven groter dan 50 ha (hoofdstuk 1), de bedrijfsresultaten naar bedrijfsgrootte (hoofdstuk 2) en de bedrijfsresultaten naar regio (hoofdstuk 3). In het afsluitende hoofdstuk 4 worden de langetermijnontwikkelingen van de particuliere bosbouw belicht. In voorgaande edities werden ook de resultaten van de kleinere bedrijven ( 5 tot 25 ha en 25 tot 50 ha) toegelicht. Voor de resultaten van deze bedrijven wordt verwezen naar bijlage 2 .

Deze bijlage geeft informatie over de omvang en samenstelling van de groep particuliere bosbedrijven (paragraaf B1.2) en over de deelnemers aan het Informatienet particuliere bosbedrijven van Wageningen Economic Research (paragraaf B1.3). Ten slotte worden de economische begrippen van de publicatie toegelicht (paragrafen B1.4 tot en met B1.7).

\section{B1.2 Particuliere bosbedrijven}

\section{Particuliere bosbezittingen}

Tot de opheffing van het Bosschap - het bedrijfschap voor bos en natuur - waren alle eigenaren van minimaal 5 ha bos verplicht geregistreerd. Daarbij werd onderscheid gemaakt tussen bosbezit in publieke hand, zoals de boseigendommen van het Rijk (waaronder Staatsbosbeheer, het Rijksvastgoedbedrijf (RVB), Defensie), provincies, waterschappen en gemeenten, en bosbezit in private handen.

De populatie van het Informatienet particuliere bosbedrijven van Wageningen Economic Research wordt gevormd door de private boseigenaren, met uitzondering van de natuurbeschermingsorganisaties. Volgens de meest recente data uit 2012 zijn er 1.520 van dergelijke bedrijven in Nederland, met een bosbezit van in totaal bijna 63.000 ha (tabel B1.1). Dat is ongeveer 17\% van het bosareaal in Nederland.

Volgens de laatste nationale bosinventarisatie (Schelhaas et al., 2014) is het Nederlandse bosareaal ruim 373.000 ha. Hiervan is circa 181.000 ha (48\%) publiek bezit, 72.000 ha (19\%) in handen van natuurbeschermingsorganisaties (inclusief Natuurmonumenten), en ongeveer 121.000 ha privaat bezit. Het private bezit is georganiseerd in verschillende rechtsvormen: bedrijf, landgoed, overig particulier georganiseerd, privé.

Het verschil tussen het privaat bezit volgens het Bosschap (63.000 ha) en de bosinventarisatie ( 121.000 ha) heeft vooral te maken met de registratiegrens van 5 ha voor het Bosschap. Verder kunnen de gehanteerde bosdefinities en een niet volledige registratie van het Bosschap een rol spelen. 
Tabel B1.1 Particuliere bosbezittingen naar oppervlakte en regio, 2012

\begin{tabular}{|c|c|c|}
\hline & Aantal bedrijven & Bosareaal (ha) \\
\hline \multicolumn{3}{|l|}{ Oppervlakte } \\
\hline 5 tot 25 ha & 904 & 10.328 \\
\hline 50 tot 100 ha & 131 & 8.850 \\
\hline 100 tot 250 ha & 70 & 10.315 \\
\hline \multicolumn{3}{|l|}{ Regio } \\
\hline Noordoost & 637 & 25.060 \\
\hline Centrum & 370 & 18.645 \\
\hline Zuid & 357 & 15.052 \\
\hline \multicolumn{3}{|l|}{ Subtotalen } \\
\hline Totaal & 1.520 & 62.754 \\
\hline
\end{tabular}

Bron: Bosschap, bewerking Wageningen Economic Research.

Indeling populatie naar omvang bosbezit en regio

Bij de opzet van het Informatienet is de populatie ingedeeld ('gestratificeerd') naar omvang van het bosbezit en de regionale ligging van de bedrijven, twee belangrijke kenmerken voor het onderzoek naar de bedrijfsuitkomsten. Van 1975 tot 1989 bestond de populatie uit bedrijven met meer dan 50 ha bos; in 1989 is de ondergrens verlaagd naar 5 ha (ondergrens van het register van het Bosschap). Dit is gedaan omdat het toenmalige ministerie van LNV en het Bosschap inzicht wilden verkrijgen in de resultaten van alle geregistreerde bedrijven. De bedrijven zijn ingedeeld in vijf oppervlakteklassen (zie tabel B1.2): 5-25 ha, 25-50 ha, 50-100 ha 100-250 ha en 250 ha en meer.

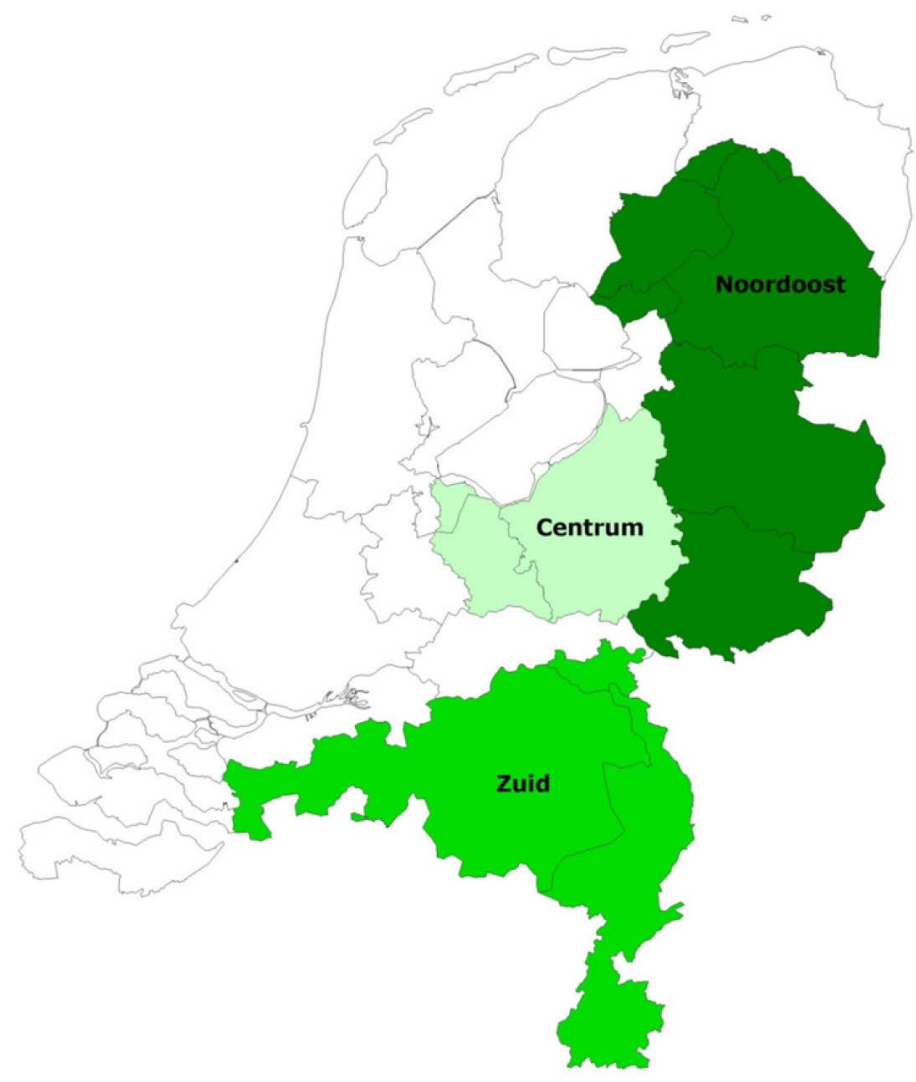

Figuur B1.1 Regio-indeling (gebaseerd op de Derde Nederlandse Bosstatistiek van het CBS) 
Het tweede criterium - regionale ligging van de particuliere bosbedrijven - is gebaseerd op de Derde Nederlandse Bosstatistiek. De daarin voorkomende acht gebieden zijn samengevoegd tot vier regio's (figuur B1.1).

Deze indeling is vanaf 1975 gelijk gebleven. De regio's zijn:

- Noordoost: ten oosten en ten noorden van de IJssel, met uitzondering van de noordelijke klei- en laagveengebieden

- Centrum: Veluwe, Utrechtse Heuvelrug en Gooi

- Zuid: Noord-Brabant en Limburg, met uitzondering van het rivierengebied

- Overig Nederland.

Uit de weinig bosrijke regio 'Overig Nederland' is geen steekproef getrokken, zodat deze regio in het rapport verder buiten beschouwing blijft. Ook in de uitkomsten per grootteklasse en voor alle bedrijven zijn de bedrijven uit Overig Nederland niet opgenomen. Hiermee komt de uiteindelijke doelpopulatie van het Informatienet uit op 1.364 particuliere bosbedrijven met een areaal bos van 58.757 ha in 2012 (tabel B1.1).

\section{B1.3 Deelnemers aan het Informatienet}

De deelnemers aan het Informatienet zijn gekozen met behulp van een steekproef uit de hiervoor genoemde doelpopulatie, die is verdeeld over vijftien subgroepen: de combinatie van vijf oppervlakteklassen en drie regio's.

Tabel B1.2 Steekproefdichtheid naar oppervlakte en regio, 2018

\begin{tabular}{|c|c|c|c|}
\hline & $\begin{array}{l}\text { Aantal steek- } \\
\text { proefbedrijven }\end{array}$ & $\begin{array}{r}\text { Steekproefbedrijven } \\
\text { in } \% \text { van de totale } \\
\text { doelpopulatie }\end{array}$ & $\begin{array}{r}\text { Steekproef- } \\
\text { oppervlakte in \% van } \\
\text { de totale oppervlakte }\end{array}$ \\
\hline 5 tot 25 ha & 38 & 4,2 & 4,4 \\
\hline 25 tot 50 ha & 27 & 12,3 & 13,7 \\
\hline 100 tot 250 ha & 29 & 41,4 & 43,2 \\
\hline 250 ha en meer & 23 & 57,5 & 64,0 \\
\hline \multicolumn{4}{|l|}{ Regio } \\
\hline Noordoost & 56 & 8,8 & 37,6 \\
\hline
\end{tabular}

Bron: Wageningen Economic Research.

Over 2018 zijn de gegevens verzameld van 144 deelnemers ('steekproefbedrijven'), ofwel $11 \%$ van het aantal bedrijven in de doelpopulatie (tabel B1.2). De steekproefbedrijven zijn samen goed voor $37 \%$ van de totale bosoppervlakte van de doelpopulatie.

\section{B1.4 Opbouw en interpretatie van het bedrijfsresultaat}

Van de bedrijven in de steekproef worden zogenaamde deeladministraties bijgehouden. Dat wil zeggen dat alleen opbrengsten en kosten die te maken hebben met het bosbedrijf worden geregistreerd. 
bedrijfsuitkomsten in de particuliere bosbouw worden beschreven aan de hand van bedrijfsresultaat, rentabiliteit, inkomen, opbrengsten en kosten uit het bosbedrijf:

- Het bedrijfsresultaat is het saldo van opbrengsten en kosten, en geeft aan of de bosbouwactiviteiten bedrijfseconomisch rendabel zijn, met andere woorden, in hoeverre de gangbare beloningsaanspraken van de productiefactoren worden gehonoreerd. Overigens zijn geen rentekosten berekend over het in grond en houtopstand geïnvesteerde vermogen.

- De rentabiliteit wordt uitgedrukt in de verhouding tussen opbrengsten en kosten (in procenten). Als deze verhouding onder de $100 \%$ ligt, blijft het resultaat achter bij de gangbare beloningsaanspraken van de productiefactoren. Hierbij wordt aangetekend dat de rentekosten in grond/opstanden niet zijn meegenomen.

- Het inkomen uit het bosbedrijf wordt berekend door het bedrijfsresultaat te vermeerderen met de berekende arbeidskosten van de eigenaar en de overige berekende lonen. Het inkomen uit het bosbedrijf geeft weer wat de beloning van de eigenaar is voor risico, management en arbeid.

- De opbrengsten bestaan uit de opbrengsten van hout, jacht en recreatie en dergelijke, en subsidies. Verhuurt een eigenaar de jacht niet, maar jaagt hij zelf, dan worden daar (normatief) opbrengsten voor in rekening gebracht.

- De kosten bestaan uit arbeidskosten, rente, afschrijving en overige kosten (zoals heffingen, verzekeringen, plantsoen en zaad, brandstoffen enzovoort). Ook worden (normatief) kosten in rekening gebracht voor de door de ondernemer en zijn gezin ingebrachte productiefactoren. Over het in grond en houtopstanden geïnvesteerde vermogen worden echter geen rentekosten berekend. De kosten zijn onder meer ingedeeld naar kostensoorten en kostenplaatsen (activiteiten/maatregelen), zoals bosverjonging, bosonderhoud en houtoogst.

Voor vergelijkingen in de tijd zijn de nominale bedragen in enkele gevallen (hoofdstuk 4) omgerekend naar reële bedragen met behulp van de prijsmutatie van het bruto binnenlands product. Als dat gebeurd is, wordt het vermeld. In alle andere gevallen zijn de bedragen nominaal.

\section{B1.5 Opbrengsten}

Houtopbrengsten

De houtopbrengsten bestaan uit het tot en met 31 december van het betreffende jaar op stam dan wel geveld verkochte hout. Het komt weinig voor dat er op 31 december niet-verkochte voorraden geveld hout op het bosbedrijf aanwezig zijn. Daarom zijn eventuele voorraadcijfers niet in de exploitatierekening van het betreffende boekjaar verwerkt. Voorschotten en afrekeningen worden verwerkt in het jaar van ontvangst.

\section{Overige houtopbrengsten}

De overige houtopbrengsten bestaan uit verkoop van afvalhout, brandhout, houtchips en boerengeriefhout.

\section{Subsidies en bijdragen}

Voor de ondersteuning van het bosbeheer zijn in de loop van de tijd verschillende subsidieprogramma's ontwikkeld. In het verleden konden boseigenaren onder meer in aanmerking komen voor een vaste hectarevergoeding van de overheid op basis van een door het Staatsbosbeheer goedgekeurd beheersplan. Met ingang van 1 september 1988 werd de Regeling Bosbijdragen samen met een aantal andere subsidieregelingen vervangen door de Regeling Bijdragen Bos- en Landschapsbouw. Hierin was een vaste bijdrage voor het onderdeel 'duurzame instandhouding' van bos opgenomen. Met ingang van 1994 is deze regeling (gedeeltelijk) vervangen door de Regeling Functiebeloning Bos en Natuurterreinen. 


\section{Programma Beheer: Subsidieregeling natuurbeheer 2000}

Per 1 januari 2000 werd voor een groot aantal bedrijven de Regeling Functiebeloning vervangen door de regelingen van het Programma Beheer. Deze regeling beoogde particulieren bij het natuurbeheer te betrekken. Er werden subsidies verstrekt op basis van zogenoemde doelpakketten. Voor particuliere boseigenaren waren de belangrijkste pakketten: (1) bos, (2) bos met verhoogde natuurwaarde en (3) natuurbos. In 2012 golden de volgende vergoedingen (provinciale regeling), ingedeeld naar soort subsidie:

- Beheersubsidie, voor instandhouding van basispakket bos (55,37 euro per ha), pluspakket bos (74,99 euro per ha) en natuurbos (83,06 euro per ha). Het terrein waarvoor subsidie is aangevraagd moet ten minste 358 dagen kosteloos worden opengesteld. De aparte toeslag voor openstelling $(10,19$ euro per ha in 2003) is vervallen. Ontheffing van de verplichting tot openstelling is in bijzondere omstandigheden mogelijk, bijvoorbeeld op grond van zwaarwegende natuurwetenschappelijke belangen.

- Inrichtingssubsidie, voor het eenmalig creëren van een betere uitgangspositie voor natuurontwikkeling.

- Recreatiesubsidie, voor het in stand houden van recreatievoorzieningen. Tegelijk met het vervallen van de openstellingstoeslag is het onderscheid tussen het 'lage' recreatiepakket (14,27 euro per ha in 2003) en 'hoge' recreatiepakket (24,46 euro per ha in 2003) verdwenen. Er was sinds 2004 één recreatiepakket voor heel het land, met een vergoeding van 33,34 euro per ha in 2012.

\section{Subsidieverordening Natuur- en Landschapsbeheer (SVNL)}

Vanaf 2012 vindt een (geleidelijke) overgang plaats van subsidiëring via het Programma Beheer naar subsidiëring via het Subsidiestelsel Natuur- en Landschap (SNL), onder de verantwoordelijkheid van de provincies. De 'Subsidieverordening Natuur- en Landschapsbeheer' (SVNL) binnen het SNL is gericht op het beheer van natuur en landschap. De modelverordening en -regeling worden jaarlijks door de gezamenlijke provincies bijgesteld en door de afzonderlijke provincies vastgesteld. Met behulp van de Index Natuur en Landschap worden de typen natuur, agrarische natuur en landschap in Nederland beschreven. De index is een gemeenschappelijke, landelijk uniforme 'natuurtaal'. Met ingang van 2018 zijn de tarieven voor 'droog bos met productiefunctie' en 'vochtig bos met productiefunctie' verhoogd tot respectievelijk circa 25 euro en 45 euro per ha.

\section{Subsidieregeling Kwaliteitsimpuls Natuur en Landschap (SKNL)}

Deze subsidieregeling binnen het Subsidiestelsel Natuur- en Landschap (SNL) is gericht op investeringen in natuur en landschap (omvorming, inrichting en kwaliteitsontwikkeling). Op basis van de SKNL kunnen Gedeputeerde Staten subsidie verstrekken voor eenmalige investeringen in bos- en natuurterreinen, met als doel de verhoging van de natuurkwaliteit van het bestaande natuurbeheertype of landschapsbeheertype, en de omzetting van een natuurterrein met een bepaald natuurbeheertype naar een ander gewenst natuurbeheertype. De hoogte van de subsidie bedraagt $95 \%$ van de goedgekeurde kosten. De provincies kunnen een maximumbedrag per hectare vaststellen. Een voorbeeld van kwaliteitsverbetering is het plaggen van een grotere oppervlakte heide om vergrassing tegen te gaan. De regeling voor kwaliteitsimpuls is in 2010 voor het eerst opengesteld.

\section{Jachthuur}

Daar elk bos een potentieel jachtgebied is, zijn de opbrengsten uit jachtverhuur in de exploitatierekening opgenomen. Indien de bossen niet voor de jacht zijn verhuurd, is ten behoeve van de wildregulatie het jachtgenot voor de eigenaar normatief als opbrengst opgenomen. Deze gegevens zijn vanaf 1981 bekend. Om een juiste vergelijking met de voorgaande jaren mogelijk te maken is deze opbrengst voor de voorliggende jaren normatief teruggerekend.

\section{Kerstbomen en -groen}

De verkopen van kerstbomen en -groen. Het betreft opbrengsten van kerstbomenuitdunningen, evenals de opbrengsten van een speciaal aangelegde kerstbomenkwekerij.

\section{Recreatie}

De recreatieopbrengsten bestaan onder meer uit de opbrengsten van een boscamping en natuur- en groepskampeerterreinen in het bos, excursies, entree-, vervoer- en parkeergelden, fietsverhuur, 
wandel-/fiets-/ruiterkaarten en visvergunningen. De opbrengsten van de werkzaamheden door vrijwilligers (bijvoorbeeld ANWB-landgoedkampeerders, scouts) worden als recreatieopbrengsten meegenomen en gelijk verondersteld aan de berekende kosten. Bij de berekening van het bedrijfsresultaat vallen de betreffende opbrengsten en kosten tegen elkaar weg.

\section{Overige bedrijfsopbrengsten}

De overige bedrijfsopbrengsten bestaan onder meer uit de verkoop van uitgangsmateriaal zoals plantsoen en zaden uit het bos, opstalrecht (ten behoeve van leidingen, zendmasten enzovoort), verhuur van bos aan derden (zoals hondenclubs, scouting, voor militaire oefeningen, rally's, crosscountry's enzovoort). Verder is hierin opgenomen de vergoeding voor schade aan het bos, zoals door brand, storm of ijzel- en sneeuwdruk.

\section{Incidentele nevenopbrengsten}

Ontvangen vergoedingen voor meestal eenmalig gebruik van (gedeeltelijke) bosterreinen, bijvoorbeeld voor slibberging. Hieronder vallen ook de opbrengsten van overgenomen herplantplichten, plantrechtsafstand van laanbomen enzovoort.

\section{B1.6 Kosten}

\section{Loon eigen personeel}

Salaris, vakantie- en eindejaarsuitkering, sociale en overige toeslagen voor personeel met een vast arbeidscontract, ten behoeve van het terreinbeheer, en salariskosten van personeel zonder vast arbeidscontract (zoals uitzendkrachten, gedetacheerden, adviseurs), ten behoeve van het terreinbeheer.

\section{Berekende lonen}

Voor niet-betaalde bosarbeid worden loonkosten op normatieve wijze berekend. Deze arbeid kan zijn verricht door de eigenaar of diens familieleden, ANWB-landgoedkampeerders, scholieren en scouts, enzovoort. Voor hun arbeid - waarvoor ze geen loon ontvangen - worden in de bedrijfseconomische boekhouding kosten opgevoerd (uren maal een normatieve uurvergoeding, ruim 10 euro in 2018). Hiermee worden de inspanningen voor het beheer zichtbaar gemaakt.

Voor de eigenaar of diens familieleden is in 2018 een bedrag van 30,81 euro per uur opgenomen. Dit is afgeleid van het gemiddelde uurloon van een bosarbeider volgens de cao-bosbouw (inclusief de wettelijk verplichte sociale lasten). Voor de managementactiviteiten van de eigenaar (beheer, leiding en toezicht) wordt een hoger uurtarief aangehouden (37,57 euro). Voor de overige categorieën (vrijwilligers) is met 10,16 euro per uur gerekend, te weten genoemd cao-loon van de bosarbeider vermenigvuldigd met een reductiefactor voor geringere vakbekwaamheid en productiviteit.

\section{Werk door derden}

De kosten voor het terreinbeheer die door derden in rekening worden gebracht, zoals de bosgroep, rentmeester, ingenieursbureau, loonwerker en een collega-natuurbeheerder. Niet opgenomen in deze post zijn de oogstkosten voor op stam verkocht hout, zowel uitdunning als eindkap. De kosten daarvan zijn in een lagere prijs per verkochte kubieke meter hout tot uiting gebracht. Onder werk door derden vallen ook de kosten van arbeid in het kader van de diverse werkgelegenheidsregelingen. De betreffende overheidsbijdrage is opgenomen onder de post 'Subsidies en bijdragen'.

Machines, werktuigen en auto's

De waarde van de machines, werktuigen en auto's die worden gebruikt voor het bosbeheer worden in samenspraak met de deelnemer getaxeerd. De afschrijvingen en rentekosten worden berekend conform de methodiek van Wageningen Economic Research voor land- en tuinbouw (Poppe, 2004). Er is gerekend met een standaardrentepercentage over het gemiddeld geïnvesteerd vermogen (het gemiddelde van de waarde op de begin- en eindbalans) in machines, werktuigen en auto's. De overige kosten van machines, werktuigen en auto's bestaan onder meer uit kosten voor onderhoud, reparatie, brandstof en verzekeringen, evenals de vergoeding (28 eurocent per kilometer) voor de door de eigenaar met zijn privéauto verreden kilometers ten behoeve van het bosbedrijf. 
Grond- en hulpstoffen

Kosten voor aangekocht zaaizaad, plantsoen, meststoffen en bestrijdingsmiddelen. De overige materialen bestaan voornamelijk uit materialen ten behoeve van wegverharding, afrasteringen, duikers enzovoort.

\section{Heffingen en verzekeringen}

Op de bossen drukkende waterschapslasten en heffingen opgelegd door het Bosschap. Met het einde van de publiekrechtelijke bedrijfsorganisatie zijn de heffingen van het Bosschap na 2014 vervallen. Indien de bossen geheel of gedeeltelijk zijn verzekerd tegen bosbrand dan wel stormschade, behoort de verschuldigde premie tot deze kostencategorie.

\section{Overige bedrijfskosten}

De overige kosten omvatten kosten van gebouwen (inclusief kantoor) in gebruik voor het bosbeheer, zoals rente en afschrijving, verzekeringen en onderhoud, kantoormateriaal, telecommunicatie en energie/water. Ook worden in deze post meegenomen: de betaalde contributies, abonnementen op vakbladen, betaalde pensioenen aan oud-bosarbeiders of hun partners, representatiekosten en de premie voor de bedrijfs-WA-verzekering.

\section{B1.7 Kostenplaatsen}

De diverse kostensoorten kunnen worden toegerekend naar kostenplaatsen, ook wel aangeduid met maatregelen of activiteiten. Deze zijn ingedeeld naar een aantal hoofdgroepen.

\section{Algemeen bosbeheer}

De algemene kosten hebben betrekking op beheer, leiding en toezicht, heffingen en verzekeringen, en overige algemene kosten (niet toe te rekenen aan activiteiten).

Onder beheer, leiding en toezicht vallen onder andere het plannen, begroten en opstellen van beheeren werkplannen, het uitbesteden en organiseren van werkzaamheden, het aanvragen van subsidies, de verkoop van hout, onderzoek en monitoring, en het toezicht op de uitvoering van werkzaamheden en de dagelijkse gang van zaken in het bos, inclusief toezicht op recreanten. De kosten voor deze activiteiten bestaan uit (berekende) lonen en betaalde kosten voor bijvoorbeeld een rentmeester, bosgroep en ingenieursbureau.

\section{Bosverjonging}

Kosten voor bodembewerking, plantwerkzaamheden voor (her)bebossing en inboetwerkzaamheden.

\section{Bosonderhoud}

De activiteiten jeugdverzorging (vrijstellen en zuiveren), opkronen, prunusbestrijding (of andere ongewenste houtopslag), onrendabele dunning (stamtaalreductie zonder ontvangsten) en het aanwijzen van toekomstbomen.

\section{Infrastructuur}

Kosten voor werkzaamheden en materialen ten behoeve van wegen, paden, waterlopen, hekken, rasters en recreatieve voorzieningen.

Houtoogst (vellingen)

Deze kosten bestaan uit arbeidskosten, werk door derden en werktuigkosten (voor zover gemaakt bij zelf uitgevoerde dunningen en kaalslagen). Met ingang van 1997 is de post 'Blessen en meten uit beheer en leiding' geplaatst onder de post 'Houtoogst'. Het betreft de kosten voor het blessen van de te vellen bomen bij een dunning, evenals het meten van het gevelde hout (zowel dunning als eindkap). Bijna altijd vindt dit plaats bij zowel op stam als geveld verkocht hout. 


\section{Bijlage 2 Tabellen}

\section{B2.1 Bedrijfsresultaten per hectare}

Tabel B2.1 Bedrijfsresultaat (euro per ha bos) particuliere bosbedrijven, 2014-2018

\begin{tabular}{|c|c|c|c|c|c|c|}
\hline Kosten & 2014 & 2015 & 2016 & 2017 & 2018 & Gemiddeld \\
\hline \multicolumn{7}{|l|}{ Arbeid (uitvoerend) } \\
\hline loon eigen personeel & 39 & 38 & 38 & 44 & 46 & 41 \\
\hline berekend loon & 31 & 35 & 38 & 40 & 47 & 38 \\
\hline totaal & 71 & 73 & 76 & 84 & 93 & 79 \\
\hline \multicolumn{7}{|l|}{ Beheer, leiding en toezicht } \\
\hline beheer en leiding & 52 & 56 & 56 & 61 & 62 & 57 \\
\hline toezicht & 26 & 29 & 27 & 31 & 35 & 30 \\
\hline blessen en meten (arbeid) & 2 & 1 & 1 & 1 & 1 & 1 \\
\hline blessen en meten (loonwerk) & 5 & 5 & 6 & 5 & 3 & 5 \\
\hline totaal & 85 & 91 & 90 & 98 & 102 & 93 \\
\hline \multicolumn{7}{|l|}{ Werk door derden } \\
\hline (her)bebossing & 5 & 4 & 8 & 12 & 5 & 7 \\
\hline bosonderhoud & 32 & 27 & 26 & 28 & 28 & 28 \\
\hline houtoogst & 6 & 9 & 13 & 14 & 21 & 13 \\
\hline infrastructuur & 10 & 14 & 9 & 13 & 14 & 12 \\
\hline totaal & 52 & 53 & 55 & 66 & 68 & 59 \\
\hline Werktuigen & 23 & 24 & 24 & 25 & 24 & 24 \\
\hline Grond- en hulpstoffen & 11 & 7 & 12 & 11 & 6 & 9 \\
\hline \multicolumn{7}{|l|}{ Grond en houtopstand } \\
\hline waterschapslasten & 4 & 4 & 4 & 4 & 4 & 4 \\
\hline heffing Bosschap & 3 & 0 & 0 & 0 & 0 & 1 \\
\hline bosbrandverzekering & 4 & 3 & 4 & 4 & 3 & 4 \\
\hline totaal & 11 & 8 & 8 & 8 & 8 & 9 \\
\hline Overige bedrijfskosten & 20 & 23 & 24 & 23 & 24 & 23 \\
\hline Totaal exploitatiekosten & 273 & 279 & 289 & 315 & 325 & 296 \\
\hline Positief bedrijfsresultaat & 39 & 14 & & & & 11 \\
\hline Totaal & 312 & 293 & 289 & 315 & 325 & 307 \\
\hline
\end{tabular}

Tabel B2.1 (vervolg) Bedrijfsresultaat (euro per ha bos) particuliere bosbedrijven, 2014-2018

\begin{tabular}{|c|c|c|c|c|c|c|}
\hline Opbrengsten & 2014 & 2015 & 2016 & 2017 & 2018 & Gemiddeld \\
\hline \multicolumn{7}{|l|}{ Houtopbrengsten } \\
\hline op stam verkocht & 132 & 120 & 101 & 90 & 106 & 110 \\
\hline geveld verkocht & 10 & 11 & 14 & 14 & 8 & 11 \\
\hline overige houtopbrengsten & 7 & 6 & 9 & 9 & 9 & 8 \\
\hline totaal houtopbrengsten & 149 & 137 & 123 & 112 & 123 & 129 \\
\hline \multicolumn{7}{|l|}{ Overig bedrijfsopbrengsten } \\
\hline jachthuur & 14 & 15 & 15 & 15 & 15 & 15 \\
\hline kerstbomen en -groen & 5 & 4 & 7 & 6 & 0 & 4 \\
\hline recreatie & 29 & 32 & 32 & 30 & 35 & 32 \\
\hline overige & 16 & 23 & 15 & 14 & 19 & 17 \\
\hline totaal & 64 & 74 & 68 & 65 & 68 & 68 \\
\hline Incidentele opbrengsten & 1 & 0 & 1 & 1 & 3 & 1 \\
\hline \multicolumn{7}{|l|}{ Subsidies en bijdragen } \\
\hline beheersubsidie & 74 & 72 & 73 & 73 & 78 & 74 \\
\hline overige & 24 & 9 & 15 & 22 & 13 & 17 \\
\hline totaal & 98 & 81 & 88 & 94 & 91 & 90 \\
\hline Totaal bedrijfsopbrengsten & 312 & 293 & 281 & 271 & 285 & 288 \\
\hline Negatief bedrijfsresultaat & & & 8 & 44 & 40 & 18 \\
\hline Totaal & 312 & 293 & 289 & 315 & 325 & 307 \\
\hline
\end{tabular}


Tabel B2.2 Bedrijfsresultaat (euro per ha bos) particuliere bosbedrijven naar bosareaal in ha, 2018

\begin{tabular}{|c|c|c|c|c|c|c|c|}
\hline Kosten & $5-25$ & $25-50$ & $50-100$ & $100-250$ & $\geq 250$ & $\begin{array}{r}\text { Totaal } \\
2018\end{array}$ & $\begin{array}{r}\text { Totaal } \\
2017\end{array}$ \\
\hline \multicolumn{8}{|l|}{ Arbeid } \\
\hline loon eigen personeel & 93 & 8 & 38 & 89 & 99 & 75 & 71 \\
\hline diverse berekende Ionen & 308 & 95 & 40 & 29 & 6 & 80 & 71 \\
\hline totaal & 401 & 104 & 78 & 118 & 105 & 155 & 141 \\
\hline \multicolumn{8}{|l|}{ Werk door derden } \\
\hline loonwerker & 49 & 39 & 68 & 83 & 55 & 58 & 62 \\
\hline rentmeester en overig & 42 & 66 & 54 & 51 & 46 & 50 & 45 \\
\hline totaal & 91 & 105 & 121 & 133 & 100 & 108 & 108 \\
\hline \multicolumn{8}{|l|}{ Werktuigen } \\
\hline rente en afschrijving & 16 & 3 & 6 & 8 & 5 & 7 & 8 \\
\hline overige werktuigkosten & 32 & 5 & 23 & 14 & 13 & 17 & 16 \\
\hline totaal & 48 & 8 & 28 & 22 & 18 & 24 & 25 \\
\hline \multicolumn{8}{|l|}{ Grond- en hulpstoffen } \\
\hline plantsoen en zaad & 1 & 2 & 3 & 6 & 5 & 3 & 5 \\
\hline mest-/bestrijdingsmiddelen & 0 & 0 & 0 & 0 & 0 & 0 & 0 \\
\hline overige grond-/hulpstoffen & 4 & 1 & 5 & 2 & 2 & 2 & 6 \\
\hline totaal & 5 & 2 & 7 & 8 & 6 & 6 & 11 \\
\hline \multicolumn{8}{|l|}{ Bosinstandhouding } \\
\hline gebouwen en infrastructuur & 24 & 2 & 3 & 1 & 0 & 5 & 4 \\
\hline grond/waterschapslasten & 4 & 6 & 4 & 5 & 4 & 4 & 4 \\
\hline heffing bosschap & 0 & 0 & 0 & 0 & 0 & 0 & 0 \\
\hline bosbrandverzekering & 4 & 5 & 4 & 5 & 2 & 3 & 4 \\
\hline totaal & 32 & 13 & 11 & 11 & 6 & 13 & 13 \\
\hline Overige bedrijfskosten & 29 & 18 & 17 & 20 & 14 & 19 & 18 \\
\hline Totaal exploitatiekosten & 609 & 249 & 263 & 312 & 250 & 325 & 315 \\
\hline Positief bedrijfsresultaat & & & & 29 & 31 & & \\
\hline Totaal & 609 & 249 & 263 & 342 & 281 & 325 & 315 \\
\hline
\end{tabular}

Tabel B2.2 (vervolg) Bedriffsresultaat (euro per ha bos) particuliere bosbedrijven naar bosareaal in ha, 2018

\begin{tabular}{|c|c|c|c|c|c|c|c|}
\hline Opbrengsten & $5-25$ & $25-50$ & $50-100$ & $100-250$ & $\geq 250$ & $\begin{array}{r}\text { Totaal } \\
2018\end{array}$ & $\begin{array}{r}\text { Totaal } \\
2017\end{array}$ \\
\hline \multicolumn{8}{|l|}{ Houtopbrengsten } \\
\hline op stam & 13 & 105 & 116 & 123 & 138 & 106 & 90 \\
\hline geveld & 29 & 1 & 5 & 0 & 5 & 8 & 14 \\
\hline overige houtopbrengsten & 13 & 3 & 5 & 9 & 10 & 9 & 9 \\
\hline totaal & 56 & 109 & 126 & 132 & 153 & 123 & 112 \\
\hline \multicolumn{8}{|l|}{ Overige bedrijfsopbrengsten } \\
\hline jachthuur & 14 & 8 & 10 & 17 & 18 & 15 & 15 \\
\hline kerstbomen en -groen & 0 & 0 & 0 & 0 & 0 & 0 & 6 \\
\hline recreatie, boscamping & 48 & 0 & 0 & 0 & 4 & 10 & 8 \\
\hline recreatie, overig & 79 & 5 & 21 & 27 & 7 & 25 & 21 \\
\hline overige & 48 & 18 & 4 & 9 & 15 & 19 & 14 \\
\hline totaal & 189 & 30 & 35 & 54 & 44 & 68 & 65 \\
\hline Incidentele opbrengsten & 0 & 5 & 13 & 0 & 1 & 3 & 1 \\
\hline \multicolumn{8}{|l|}{ Subsidies en bijdragen } \\
\hline beheersubsidie & 58 & 70 & 70 & 117 & 76 & 78 & 73 \\
\hline overige subsidies & 17 & 1 & 5 & 39 & 7 & 13 & 22 \\
\hline totaal & 75 & 70 & 75 & 156 & 83 & 91 & 94 \\
\hline Totaal bedrijfsopbrengsten & 319 & 215 & 250 & 342 & 281 & 285 & 271 \\
\hline Negatief bedrijfsresultaat & 289 & 35 & 13 & & & 40 & 44 \\
\hline Totaal & 609 & 249 & 263 & 342 & 281 & 325 & 315 \\
\hline
\end{tabular}


Tabel B2.3 Bedrijfsresultaten (euro per ha bos) alle bedrijven naar regio, 2018

\begin{tabular}{|c|c|c|c|c|c|}
\hline Kosten & Noordoost & Centrum & Zuid & Totaal 2018 & Totaal 2017 \\
\hline \multicolumn{6}{|l|}{ Arbeid } \\
\hline Ioon eigen personeel & 68 & 118 & 36 & 75 & 71 \\
\hline totaal & 158 & 228 & 62 & 155 & 141 \\
\hline \multicolumn{6}{|l|}{ Werk door derden } \\
\hline totaal & 101 & 139 & 81 & 108 & 108 \\
\hline \multicolumn{6}{|l|}{ Werktuigen } \\
\hline rente en afschrijving & 10 & 8 & 2 & 7 & 8 \\
\hline overige werktuigkosten & 15 & 28 & 7 & 17 & 16 \\
\hline mest- en bestrijdingsmiddelen & 0 & 0 & 0 & 0 & 0 \\
\hline overige grond- en hulpstoffen & 2 & 5 & 1 & 2 & 6 \\
\hline totaal & 6 & 9 & 2 & 6 & 11 \\
\hline \multicolumn{6}{|l|}{ Bosinstandhouding } \\
\hline gebouwen en infrastructuur & 1 & 15 & 0 & 5 & 4 \\
\hline grond-/waterschapslasten & 5 & 4 & 3 & 4 & 4 \\
\hline heffing bosschap & 0 & 0 & 0 & 0 & 0 \\
\hline bosbrandverzekering & 3 & 5 & 3 & 3 & 4 \\
\hline totaal & 9 & 25 & 6 & 13 & 13 \\
\hline
\end{tabular}

Tabel B2.3 (vervolg) Bedrijfsresultaten (euro per ha bos) alle bedrijven naar regio, 2018

\begin{tabular}{|c|c|c|c|c|c|}
\hline Opbrengsten & Noordoost & Centrum & Zuid & Totaal 2018 & Totaal 2017 \\
\hline \multicolumn{6}{|l|}{ Houtopbrengsten } \\
\hline op stam & 117 & 122 & 68 & 106 & 90 \\
\hline overige houtopbrengsten & 10 & 14 & 1 & 9 & 9 \\
\hline totaal & 142 & 139 & 72 & 123 & 112 \\
\hline kerstbomen en -groen & 0 & 0 & 0 & 0 & 6 \\
\hline recreatie, boscamping & 3 & 27 & 0 & 10 & 8 \\
\hline recreatie, overige opbrengst & 9 & 54 & 16 & 25 & 21 \\
\hline overige & 11 & 40 & 7 & 19 & 14 \\
\hline beheersubsidie & 81 & 85 & 65 & 78 & 73 \\
\hline overige subsidies & 26 & 5 & 1 & 13 & 22 \\
\hline totaal & 106 & 90 & 66 & 91 & 94 \\
\hline Totaal bedrijfsopbrengsten & 281 & 381 & 174 & 285 & 271 \\
\hline Negatief bedrijfsresultaat & 35 & 84 & & 40 & 44 \\
\hline Totaal & 316 & 466 & 174 & 325 & 315 \\
\hline
\end{tabular}


Tabel B2.4 Kosten arbeid en loonwerk (euro per ha bos) particuliere bosbedrijven naar omvang bosareaal in ha, 2018

\begin{tabular}{|c|c|c|c|c|c|c|c|}
\hline Kosten & $5-25$ & $25-50$ & $50-100$ & $100-250$ & $\geq 250$ & $\begin{array}{r}\text { Totaal } \\
2018\end{array}$ & $\begin{array}{r}\text { Totaal } \\
2017\end{array}$ \\
\hline \multicolumn{8}{|c|}{ Arbeid, betaald loon eigen personeel } \\
\hline beheer en leiding & 11 & 0 & 3 & 12 & 24 & 14 & 14 \\
\hline toezicht & 4 & 3 & 11 & 28 & 20 & 15 & 12 \\
\hline bosverjonging & 0 & 0 & 0 & 3 & 5 & 2 & 4 \\
\hline bosverzorging & 48 & 2 & 21 & 33 & 36 & 31 & 29 \\
\hline houtoogst & 0 & 0 & 2 & 5 & 5 & 3 & 3 \\
\hline infrastructuur & 30 & 3 & 0 & 7 & 8 & 10 & 9 \\
\hline totaal & 93 & 8 & 38 & 89 & 99 & 75 & 71 \\
\hline \multicolumn{8}{|l|}{ Arbeid, berekend loon } \\
\hline beheer en leiding & 49 & 42 & 11 & 11 & 2 & 18 & 17 \\
\hline toezicht & 51 & 18 & 7 & 5 & 1 & 14 & 13 \\
\hline bosverjonging & 2 & 4 & 1 & 0 & 0 & 1 & 1 \\
\hline bosverzorging & 141 & 15 & 13 & 10 & 4 & 32 & 25 \\
\hline houtoogst & 32 & 14 & 8 & 2 & 0 & 9 & 6 \\
\hline infrastructuur & 32 & 3 & 1 & 1 & 0 & 6 & 9 \\
\hline totaal & 308 & 95 & 40 & 29 & 6 & 80 & 71 \\
\hline \multicolumn{8}{|l|}{ Loonwerk } \\
\hline beheer en leiding & 24 & 31 & 37 & 47 & 24 & 31 & 31 \\
\hline toezicht & 28 & 3 & 2 & 3 & 0 & 6 & 6 \\
\hline bosverjonging & 1 & 1 & 8 & 3 & 8 & 5 & 12 \\
\hline bosverzorging & 19 & 47 & 26 & 37 & 22 & 28 & 28 \\
\hline houtoogst & 19 & 19 & 32 & 23 & 27 & 25 & 18 \\
\hline infrastructuur & 0 & 5 & 16 & 20 & 19 & 14 & 13 \\
\hline totaal & 91 & 105 & 121 & 133 & 100 & 108 & 107 \\
\hline Overige kosten & 117 & 40 & 64 & 60 & 45 & 62 & 66 \\
\hline Totaal & 609 & 249 & 263 & 312 & 250 & 325 & 315 \\
\hline
\end{tabular}

Tabel B2.5 Kosten arbeid en loonwerk (euro per ha bos) particuliere bosbedrijven naar regio, 2018

\begin{tabular}{|c|c|c|c|c|c|}
\hline Kosten & Noordoost & Centrum & Zuid & Totaal 2018 & Totaal 2017 \\
\hline \multicolumn{6}{|c|}{ Arbeid, betaald loon eigen personeel } \\
\hline beheer en leiding & 12 & 16 & 14 & 14 & 14 \\
\hline toezicht & 15 & 16 & 14 & 15 & 12 \\
\hline bosverjonging & 5 & 1 & 0 & 2 & 4 \\
\hline bosverzorging & 23 & 64 & 5 & 31 & 29 \\
\hline houtoogst & 6 & 2 & 0 & 3 & 3 \\
\hline infrastructuur & 9 & 19 & 2 & 10 & 9 \\
\hline totaal & 68 & 118 & 36 & 75 & 71 \\
\hline \multicolumn{6}{|l|}{ Arbeid, berekend loon } \\
\hline beheer en leiding & 20 & 24 & 7 & 18 & 17 \\
\hline toezicht & 20 & 7 & 11 & 14 & 13 \\
\hline bosverjonging & 1 & 1 & 1 & 1 & 1 \\
\hline bosverzorging & 31 & 56 & 4 & 32 & 25 \\
\hline houtoogst & 14 & 8 & 1 & 9 & 6 \\
\hline infrastructuur & 4 & 13 & 2 & 6 & 9 \\
\hline totaal & 90 & 110 & 26 & 80 & 71 \\
\hline \multicolumn{6}{|l|}{ Loonwerk } \\
\hline beheer en leiding & 30 & 35 & 27 & 31 & 31 \\
\hline toezicht & 1 & 9 & 11 & 6 & 6 \\
\hline bosverjonging & 3 & 9 & 2 & 5 & 12 \\
\hline bosverzorging & 16 & 46 & 26 & 28 & 28 \\
\hline houtoogst & 36 & 22 & 8 & 25 & 18 \\
\hline infrastructuur & 15 & 17 & 7 & 14 & 13 \\
\hline totaal & 101 & 139 & 81 & 108 & 107 \\
\hline Overige kosten & 56 & 98 & 28 & 62 & 66 \\
\hline Totaal & 316 & 466 & 171 & 325 & 315 \\
\hline
\end{tabular}


Tabel B2.6 Bedrijfsresultaten (euro per ha bos) particuliere bosbedrijven groter dan 50 ha, 2014-2018

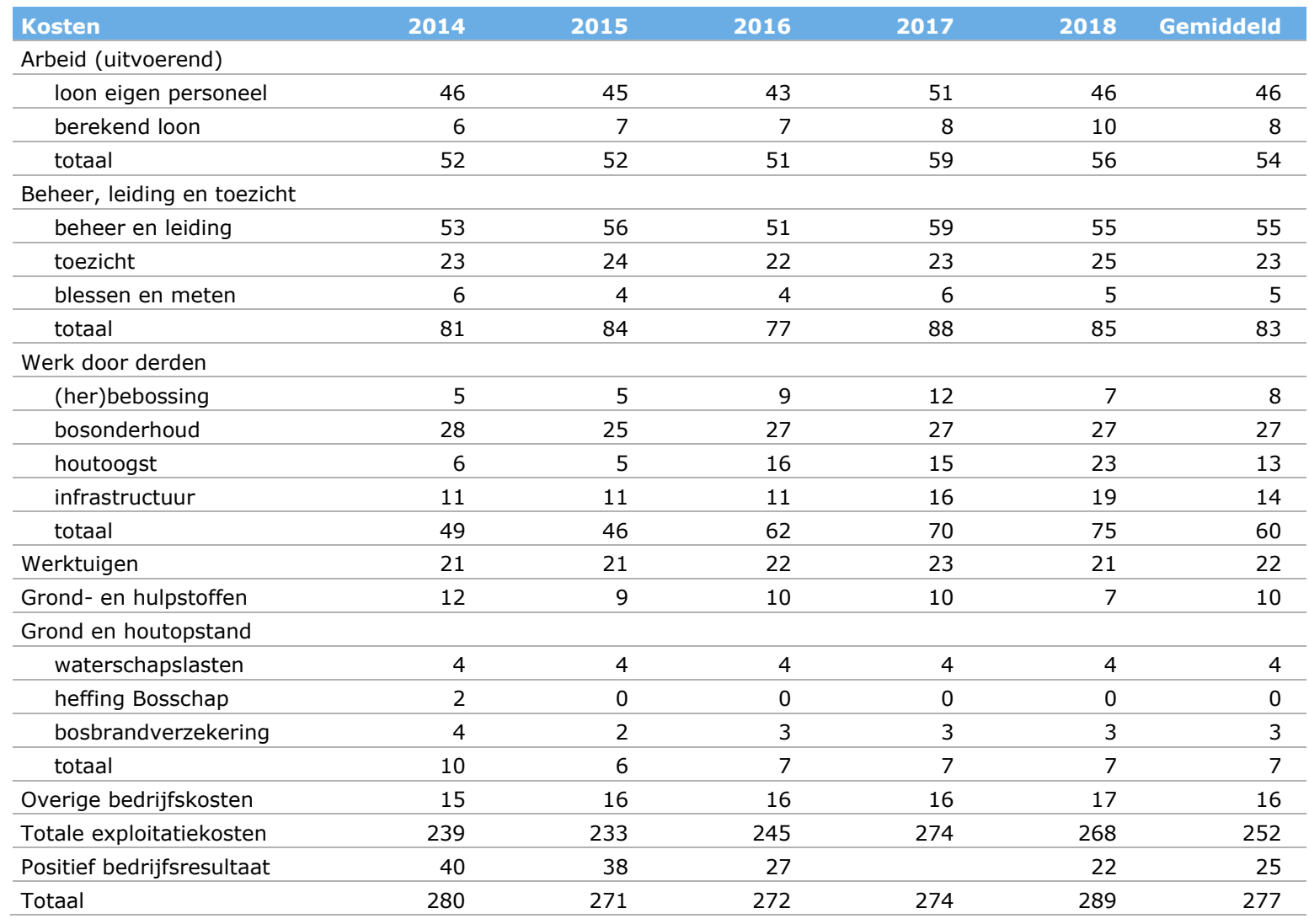

Tabel B2.6 (vervolg) Bedrijfsresultaten (euro per ha bos) particuliere bosbedrijven groter dan 50 ha, 2014-2018

\begin{tabular}{|c|c|c|c|c|c|c|}
\hline Opbrengsten & 2014 & 2015 & 2016 & 2017 & 2018 & Gemiddeld \\
\hline \multicolumn{7}{|l|}{ Houtopbrengsten } \\
\hline op stam verkocht & 121 & 114 & 116 & 111 & 130 & 118 \\
\hline overige houtopbrengsten & 7 & 7 & 8 & 9 & 9 & 8 \\
\hline totaal houtopbrengsten & 136 & 129 & 136 & 126 & 142 & 134 \\
\hline kerstbomen en -groen & 0 & 0 & 0 & 0 & 0 & 0 \\
\hline recreatie & 15 & 15 & 15 & 13 & 17 & 15 \\
\hline overige & 12 & 21 & 9 & 9 & 12 & 13 \\
\hline totaal & 45 & 54 & 41 & 39 & 45 & 45 \\
\hline overige & 15 & 10 & 16 & 28 & 14 & 17 \\
\hline totaal & 96 & 87 & 93 & 105 & 99 & 96 \\
\hline Totale bedrijfsopbrengsten & 280 & 271 & 272 & 271 & 289 & 277 \\
\hline Negatief bedrijfsresultaat & & & & 3 & & 1 \\
\hline Totaal & 280 & 271 & 272 & 274 & 289 & 277 \\
\hline
\end{tabular}


Tabel B2.7 Bedrijfsresultaten (euro per ha bos) particuliere bosbedrijven groter dan 50 ha naar regio, 2018

\begin{tabular}{|c|c|c|c|c|c|}
\hline Kosten & Noordoost & Centrum & Zuid & Totaal 2018 & Totaal 2017 \\
\hline \multicolumn{6}{|l|}{ Arbeid } \\
\hline Ioon eigen personeel & 100 & 87 & 51 & 84 & 87 \\
\hline totaal & 125 & 99 & 69 & 103 & 107 \\
\hline \multicolumn{6}{|l|}{ Werk door derden } \\
\hline totaal & 114 & 129 & 87 & 113 & 111 \\
\hline \multicolumn{6}{|l|}{ Werktuigen } \\
\hline rente en afschrijving & 9 & 4 & 2 & 6 & 7 \\
\hline overige werktuigkosten & 16 & 19 & 9 & 15 & 16 \\
\hline mest en bestrijdingsmiddel & 0 & 0 & 0 & 0 & 0 \\
\hline overige grond- en hulpstoffen & 2 & 4 & 0 & 2 & 5 \\
\hline totaal & 8 & 9 & 2 & 7 & 10 \\
\hline \multicolumn{6}{|l|}{ Bosinstandhouding } \\
\hline gebouwen en infrastructuur & 2 & 1 & 0 & 1 & 1 \\
\hline grond-/waterschapslasten & 5 & 3 & 3 & 4 & 4 \\
\hline heffing bosschap & 0 & 0 & 0 & 0 & 0 \\
\hline bosbrandverzekering & 3 & 3 & 4 & 3 & 3 \\
\hline totaal & 10 & 7 & 6 & 8 & 8 \\
\hline Overige bedrijfskosten & 16 & 21 & 10 & 16 & 15 \\
\hline
\end{tabular}

Tabel B2.7 (vervolg) Bedrijfsresultaten (euro per ha bos) particuliere bosbedrijven groter dan 50 ha naar regio, 2018

\begin{tabular}{|c|c|c|c|c|c|}
\hline Opbrengsten & Noordoost & Centrum & Zuid & Totaal 2018 & Totaal 2017 \\
\hline \multicolumn{6}{|l|}{ Houtopbrengsten } \\
\hline op stam & 157 & 122 & 93 & 130 & 111 \\
\hline overige houtopbrengsten & 8 & 16 & 1 & 9 & 9 \\
\hline totaal & 173 & 139 & 94 & 142 & 126 \\
\hline kerstbomen en -groen & 0 & 0 & 0 & 0 & 0 \\
\hline recreatie, boscamping & 5 & 0 & 0 & 2 & 3 \\
\hline recreatie, overige opbrengst & 12 & 11 & 25 & 15 & 10 \\
\hline overige & 16 & 7 & 10 & 12 & 9 \\
\hline overige subsidies & 29 & 4 & 1 & 14 & 28 \\
\hline totaal & 113 & 101 & 71 & 99 & 105 \\
\hline Totaal bedrijfsopbrengsten & 330 & 295 & 211 & 289 & 271 \\
\hline Negatief bedrijfsresultaat & & & & & 3 \\
\hline Totaal & 330 & 295 & 211 & 289 & 274 \\
\hline
\end{tabular}


Tabel B2.8 Kosten arbeid en loonwerk (euro per ha bos) particuliere bosbedrijven groter dan 50 ha naar regio, 2018

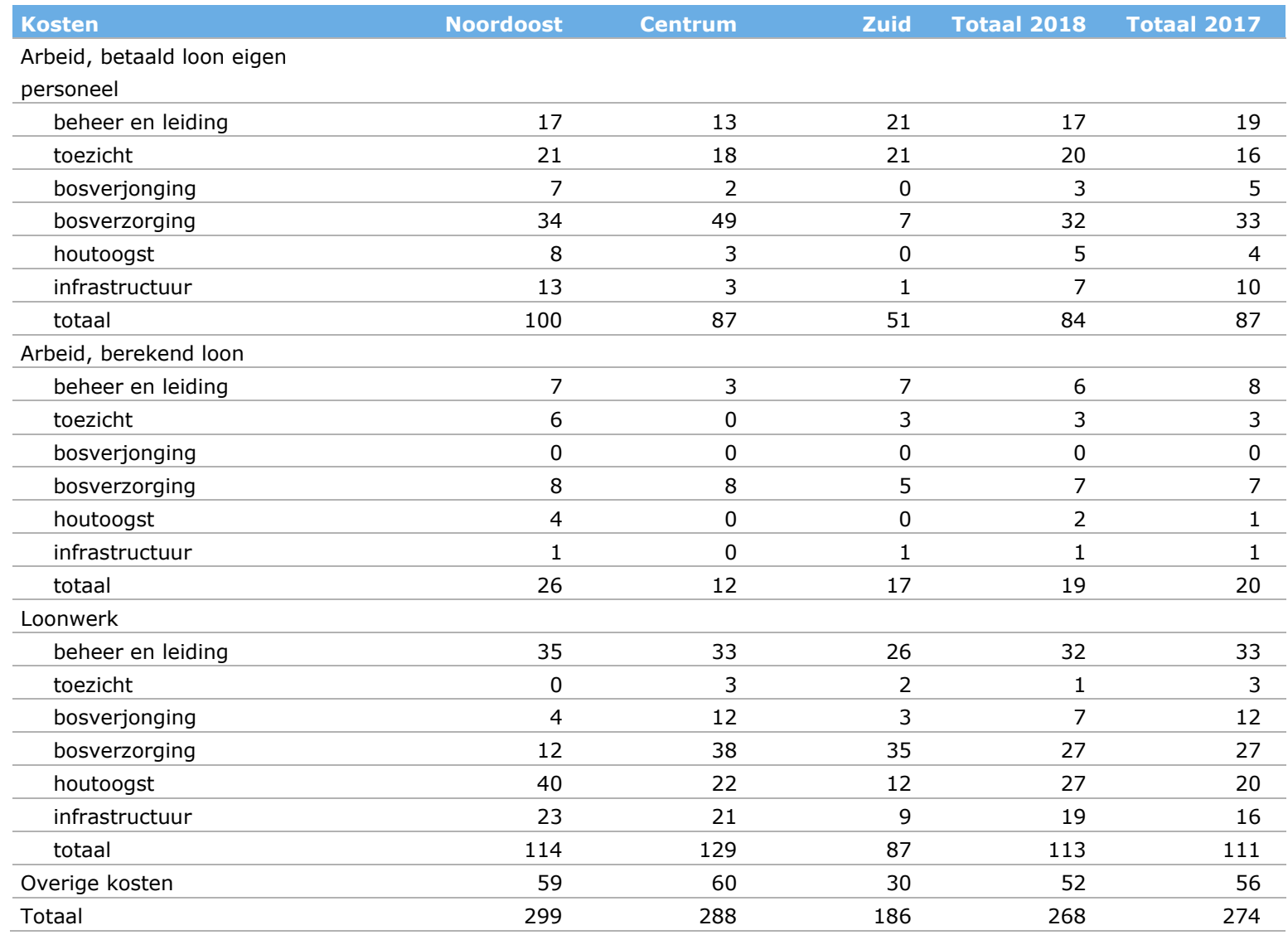




\section{B2.2 Kosten naar kostenplaatsen}

Tabel B2.9 Kosten (euro per ha bos) alle bedrijven naar kostenplaats en omvang bosareaal in ha, 2018

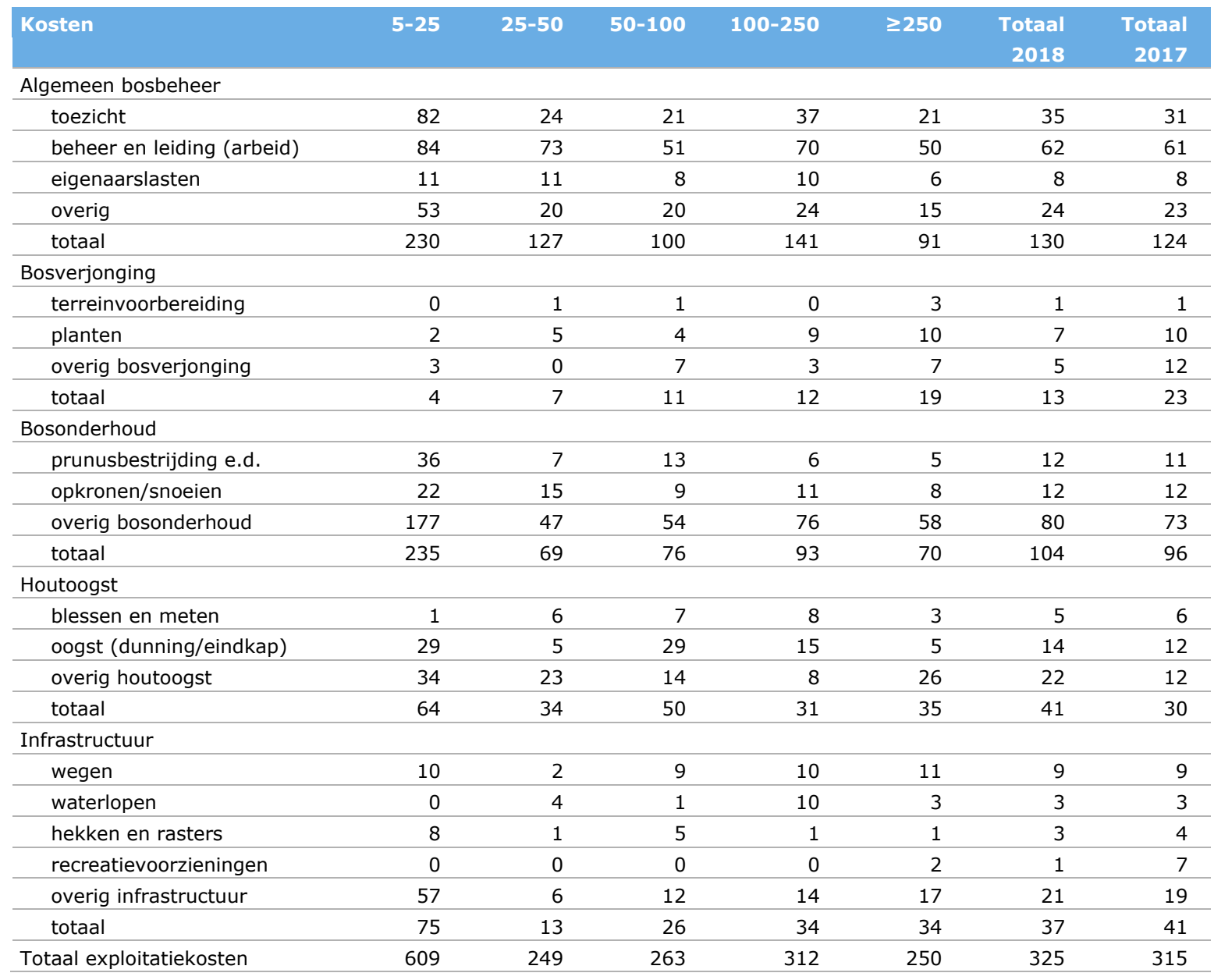


Tabel B2.10Kosten (euro per ha bos) alle bedrijven naar kostenplaats en regio, 2018

\begin{tabular}{|c|c|c|c|c|c|}
\hline Kosten & Noordoost & Centrum & Zuid & Totaal 2018 & Totaal 2017 \\
\hline \multicolumn{6}{|l|}{ Algemeen bosbeheer } \\
\hline toezicht & 36 & 32 & 36 & 35 & 31 \\
\hline eigenaarslasten & 8 & 10 & 6 & 8 & 8 \\
\hline overig & 19 & 43 & 12 & 24 & 23 \\
\hline terreinvoorbereiding & 1 & 1 & 2 & 1 & 1 \\
\hline planten & 9 & 8 & 2 & 7 & 10 \\
\hline overig bosverjonging & 4 & 9 & 0 & 5 & 12 \\
\hline totaal & 14 & 17 & 4 & 13 & 23 \\
\hline overig bosonderhoud & 56 & 153 & 32 & 80 & 73 \\
\hline totaal & 81 & 188 & 40 & 104 & 96 \\
\hline \multicolumn{6}{|l|}{ Houtoogst } \\
\hline blessen en meten & 5 & 7 & 1 & 5 & 6 \\
\hline oogst (dunning/eindkap) & 24 & 7 & 7 & 14 & 12 \\
\hline overig houtoogst & 32 & 25 & 3 & 22 & 12 \\
\hline totaal & 61 & 40 & 10 & 41 & 30 \\
\hline \multicolumn{6}{|l|}{ Infrastructuur } \\
\hline wegen & 10 & 13 & 3 & 9 & 9 \\
\hline waterlopen & 4 & 3 & 2 & 3 & 3 \\
\hline
\end{tabular}


Tabel B2.11 Kosten (euro per ha bos) particuliere bosbedrijven groter dan 50 ha naar kostenplaats en regio, 2018

\begin{tabular}{|c|c|c|c|c|c|}
\hline Kosten & Noordoost & Centrum & Zuid & Totaal 2018 & Totaal 2017 \\
\hline \multicolumn{6}{|l|}{ Algemeen bosbeheer } \\
\hline toezicht & 27 & 21 & 26 & 25 & 23 \\
\hline eigenaarslasten & 8 & 6 & 6 & 7 & 7 \\
\hline overig & 20 & 21 & 11 & 18 & 16 \\
\hline terreinvoorbereiding & 1 & 1 & 3 & 2 & 1 \\
\hline planten & 11 & 10 & 2 & 9 & 10 \\
\hline overig bosverjonging & 6 & 9 & 0 & 6 & 14 \\
\hline totaal & 18 & 20 & 6 & 16 & 25 \\
\hline overig bosonderhoud & 47 & 94 & 43 & 62 & 63 \\
\hline totaal & 64 & 109 & 55 & 77 & 81 \\
\hline \multicolumn{6}{|l|}{ Houtoogst } \\
\hline blessen en meten & 6 & 7 & 0 & 5 & 6 \\
\hline oogst (dunning/eindkap) & 20 & 5 & 10 & 13 & 11 \\
\hline overig houtoogst & 30 & 17 & 3 & 19 & 9 \\
\hline totaal & 57 & 30 & 14 & 37 & 27 \\
\hline \multicolumn{6}{|l|}{ Infrastructuur } \\
\hline wegen & 15 & 11 & 1 & 10 & 10 \\
\hline
\end{tabular}




\section{B2.3 Houtoogst en opbrengstprijzen}

Tabel B2.12 Houtoogst ( $m^{3}$ per ha bos) naar omvang bos in ha, 1989-2018

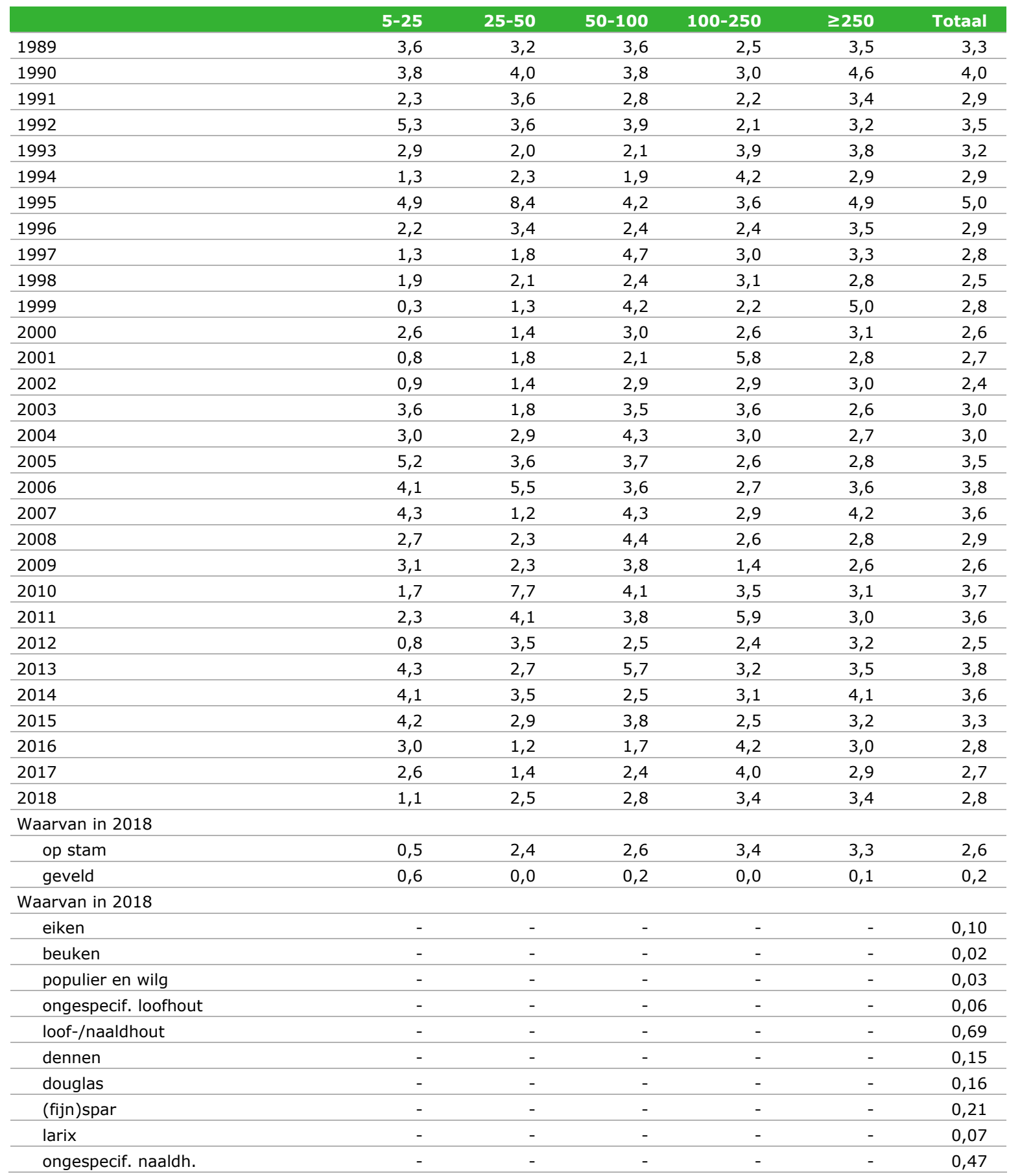


Tabel B2.13 Opbrengstprijzen (euro per $\mathrm{m}^{3}$ ) op stam en geveld verkocht hout naar regio, 1996-2018

\begin{tabular}{|c|c|c|c|c|}
\hline $\begin{array}{l}\text { Verkoopwijze, } \\
\text { oogstmethode }\end{array}$ & Noordoost & Centrum & Zuid & Totaal \\
\hline \multicolumn{5}{|c|}{ Op stam verkocht, dunning } \\
\hline 1997 & 10,5 & 14,6 & 10,8 & 12,2 \\
\hline 1998 & 14,6 & 15,6 & 10,4 & 13,8 \\
\hline 2001 & 7,7 & 15,4 & 12,1 & 11,9 \\
\hline 2002 & 15,0 & 17,2 & 10,6 & 14,6 \\
\hline 2003 & 14,4 & 14,7 & 9,9 & 12,6 \\
\hline 2004 & 14,8 & 12.2 & 12,3 & 13,3 \\
\hline 2008 & 22,4 & 27,5 & 24,7 & 24,0 \\
\hline 2009 & 26,5 & 24,4 & 16,8 & 23,4 \\
\hline \multicolumn{5}{|c|}{ Op stam verkocht, eindkap } \\
\hline 1996 & 16,1 & 18,2 & 14,9 & 15,8 \\
\hline 1997 & 15,1 & 12,3 & 14,4 & 14,0 \\
\hline 1998 & 17,8 & 17,6 & 9,3 & 15,9 \\
\hline 1999 & 6,8 & 15,3 & 17,8 & 10,3 \\
\hline 2000 & 17,0 & 13,6 & 24,0 & 18,2 \\
\hline 2001 & 17,1 & 19,3 & 20,0 & 18,0 \\
\hline 2002 & 14,4 & 19,0 & 16,7 & 16,0 \\
\hline 2009 & - & 40,8 & 10,0 & 30,8 \\
\hline \multicolumn{5}{|c|}{ Op stam verkocht (dunning en eindkap) } \\
\hline 2010 & 30,8 & 39,2 & 19,0 & 27,9 \\
\hline 2011 & 33,7 & 38,3 & 27,2 & 34,3 \\
\hline 2012 & 34,6 & 49,3 & 28,1 & 37,6 \\
\hline 2013 & 39,4 & 36,8 & 33,1 & 37,6 \\
\hline 2014 & 43,4 & 37,9 & 25,1 & 38,0 \\
\hline 2015 & 37,8 & 47,0 & 31,7 & 38,2 \\
\hline 2016 & 39,7 & 42,2 & 32,7 & 39,6 \\
\hline 2017 & 39,3 & 41,5 & 23,3 & 36,2 \\
\hline 2018 & 40,2 & 42,7 & 36,4 & 40,9 \\
\hline
\end{tabular}


Tabel B2.13 (vervolg) Opbrengstprijzen (euro per $\mathrm{m}^{3}$ ) op stam en geveld verkocht hout naar regio, 1996-2018

\begin{tabular}{|c|c|c|c|c|}
\hline $\begin{array}{l}\text { Verkoopwijze, } \\
\text { oogstmethode }\end{array}$ & Noordoost & Centrum & Zuid & Totaal \\
\hline \multicolumn{5}{|c|}{ Geveld verkocht, dunning } \\
\hline 1997 & 29,5 & 28,6 & 27,3 & 28,6 \\
\hline 1998 & 26,5 & 19,0 & 22,8 & 24,0 \\
\hline 2001 & 30,9 & 28,4 & 22,9 & 29,4 \\
\hline 2002 & 28,0 & 33,6 & 22,4 & 28,5 \\
\hline 2003 & 32,3 & 36,4 & 15,0 & 31,0 \\
\hline 2004 & 21,5 & 33,4 & 18,5 & 23,3 \\
\hline 2008 & 41,5 & 42,5 & 50,4 & 41,9 \\
\hline 2009 & 33,1 & 69,6 & 44,5 & 43,5 \\
\hline \multicolumn{5}{|c|}{ Geveld verkocht, eindkap } \\
\hline 1996 & 25,0 & 16,4 & - & 23,1 \\
\hline 1997 & 28,5 & - & - & 28,5 \\
\hline 1998 & 17,8 & 43,5 & - & 21,0 \\
\hline 1999 & 34,1 & 29,9 & 40,8 & 34,2 \\
\hline 2000 & - & 24,1 & - & 24,1 \\
\hline 2001 & 41,3 & 24,4 & - & 33,1 \\
\hline 2002 & 30,7 & 41,6 & - & 39,3 \\
\hline 2009 & 29,3 & - & - & 29,3 \\
\hline \multicolumn{5}{|c|}{ Geveld verkocht (dunning en eindkap) } \\
\hline 2010 & 43,0 & 52,4 & 33,9 & 45,6 \\
\hline 2011 & 50,1 & 57,3 & - & 51,0 \\
\hline 2012 & 50,8 & 61,1 & - & 54,2 \\
\hline 2013 & 45,4 & 34,7 & - & 40,4 \\
\hline 2014 & 59,5 & 79,5 & - & 61,8 \\
\hline 2015 & 52,0 & - & - & 54,8 \\
\hline 2016 & 64,3 & 56,5 & - & 62,5 \\
\hline 2017 & 51,6 & - & - & 59,5 \\
\hline 2018 & 55,0 & - & - & 52,5 \\
\hline
\end{tabular}


Tabel B2.14Opbrengstprijzen (euro per $\mathrm{m}^{3}$ ) op stam en geveld verkocht hout naar omvang bosareaal in ha, 1996-2018

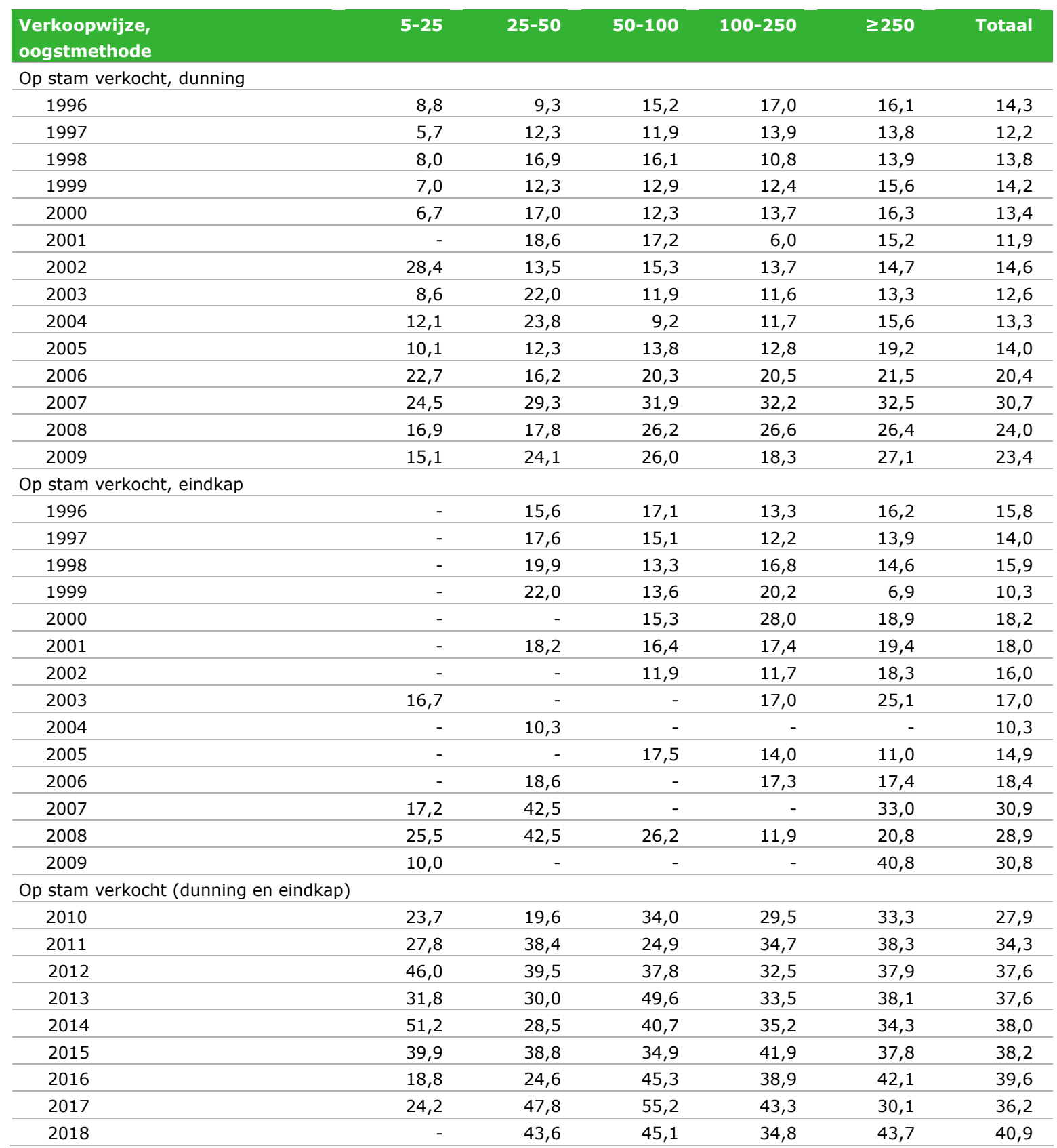


Tabel B2.14 (vervolg) Opbrengstprijzen (euro per $\mathrm{m}^{3}$ ) op stam en geveld verkocht hout naar omvang bosareaal in ha, 1996-2018

\begin{tabular}{|c|c|c|c|c|c|c|}
\hline $\begin{array}{l}\text { Verkoopwijze, } \\
\text { oogstmethode }\end{array}$ & $5-25$ & 25-50 & $50-100$ & $100-250$ & $\geq 250$ & Totaal \\
\hline \multicolumn{7}{|c|}{ Geveld verkocht, dunning } \\
\hline 1996 & 20,8 & 27,6 & 26,5 & 27,8 & 32,9 & 27,5 \\
\hline 1997 & 27,6 & 27,0 & 25,6 & 27,9 & 30,8 & 28,6 \\
\hline 1998 & 14,5 & 20,9 & 25,1 & 33,1 & 42,9 & 24,0 \\
\hline 1999 & 22,3 & 18,8 & 27,1 & 19,1 & 42,7 & 33,4 \\
\hline 2000 & 23,8 & 24,1 & 25,1 & 19,0 & 36,0 & 28,3 \\
\hline 2001 & 24,1 & 28,5 & 18,0 & 31,6 & 36,6 & 29,4 \\
\hline 2002 & 26,4 & 12,3 & 22,0 & 23,2 & 36,3 & 28,5 \\
\hline 2003 & 25,9 & 19,6 & 33,0 & 20,3 & 39,5 & 31,0 \\
\hline 2004 & 14,1 & 28,1 & 27,1 & 31,4 & 32,3 & 23,3 \\
\hline 2005 & 29,0 & 40,6 & 20,1 & 35,1 & 36,3 & 33,1 \\
\hline 2006 & 38,2 & 17,9 & 30,0 & 33,0 & 39,3 & 37,4 \\
\hline 2007 & 35,0 & 34,9 & 57,4 & 28,7 & 47,7 & 40,9 \\
\hline 2008 & 33,6 & 39,9 & 35,8 & 38,8 & 50,2 & 41,9 \\
\hline 2009 & 64,0 & 43,9 & 28,2 & 50,7 & 30,2 & 43,5 \\
\hline \multicolumn{7}{|c|}{ Geveld verkocht, eindkap } \\
\hline 1996 & - & 6,8 & - & 25,0 & 21,1 & 23,1 \\
\hline 1997 & - & - & 26,5 & 35,3 & 27,3 & 28,5 \\
\hline 1998 & 13,3 & - & 23,7 & 29,2 & 42,8 & 21,0 \\
\hline 1999 & - & 43,2 & - & 28,5 & 25,6 & 34,2 \\
\hline 2000 & - & - & - & - & 24,1 & 24,1 \\
\hline 2001 & - & 41,3 & - & - & 24,4 & 33,1 \\
\hline 2002 & - & - & - & - & - & 39,3 \\
\hline 2003 & 15,0 & - & - & - & - & 15,0 \\
\hline 2004 & - & - & - & 25,2 & - & 34,8 \\
\hline 2005 & - & - & - & 26,2 & - & 26,2 \\
\hline 2006 & 30,0 & - & - & 24,9 & - & 25,8 \\
\hline 2007 & - & - & - & 39,9 & - & 39,9 \\
\hline 2008 & - & - & - & 36,9 & - & 36,9 \\
\hline 2009 & 30,0 & - & - & 28,0 & - & 29,3 \\
\hline \multicolumn{7}{|c|}{ Geveld verkocht (dunning en eindkap) } \\
\hline 2010 & 56,4 & 67,8 & 50,0 & 34,8 & 41,0 & 45,6 \\
\hline 2011 & 56,5 & 47,8 & - & 48,2 & 34,1 & 51,0 \\
\hline 2012 & 54,1 & - & - & - & 55,1 & 54,2 \\
\hline 2013 & 53,9 & 32,3 & - & - & 41,8 & 40,4 \\
\hline 2014 & 65,6 & 46,0 & - & - & 66,7 & 61,8 \\
\hline 2015 & 60,5 & 42,8 & - & - & 51,8 & 54,8 \\
\hline 2016 & 61,5 & - & - & 53,1 & 68,7 & 62,5 \\
\hline 2017 & 83,6 & 39,6 & 57,7 & 51,0 & 64,5 & 59,5 \\
\hline 2018 & 57,1 & - & - & - & - & 52,5 \\
\hline
\end{tabular}


Tabel B2.15Opbrengstprijzen (euro per $\mathrm{m}^{3}$ ) naar houtsoort en verkoopwijze, 2014-2018

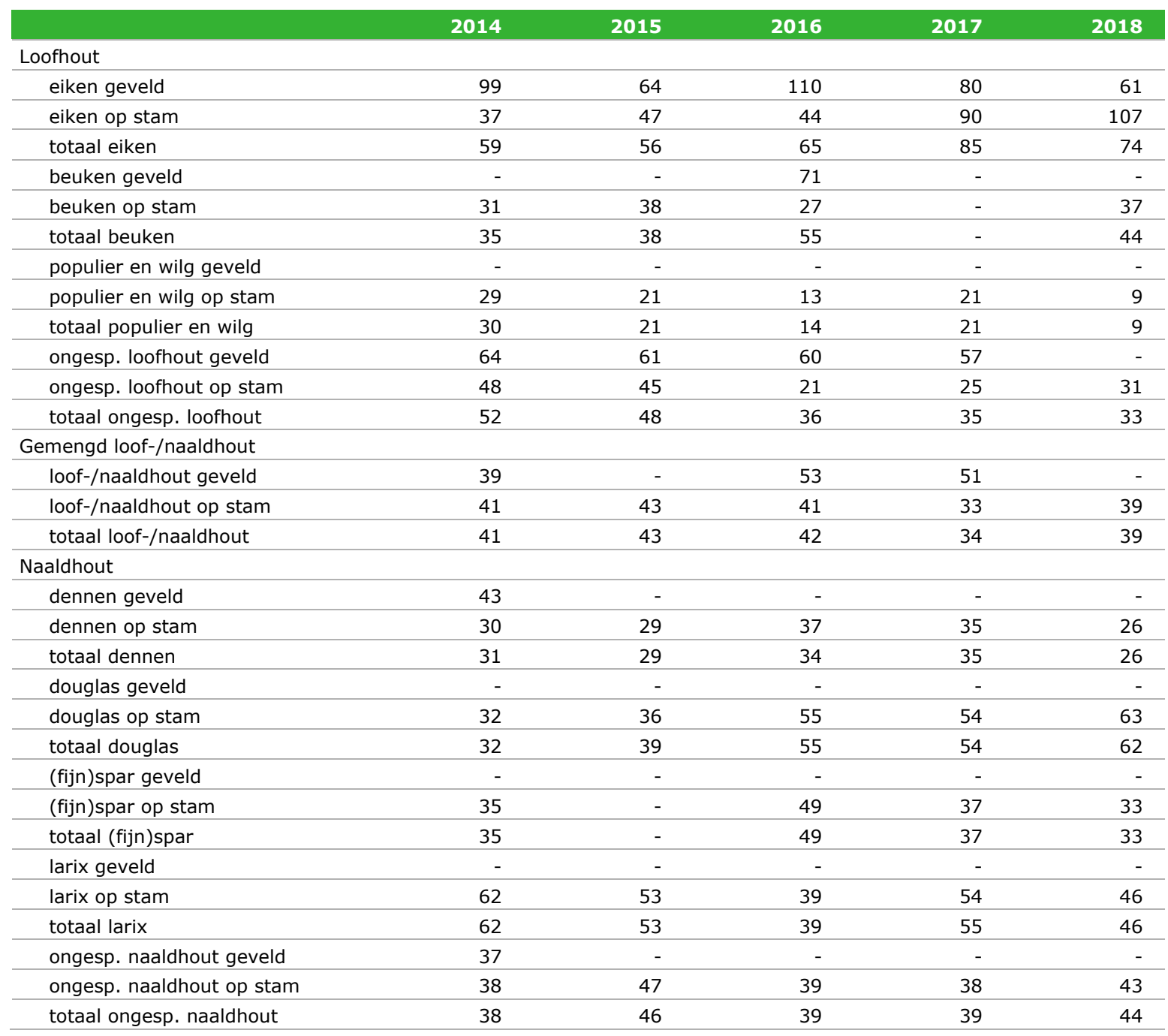


Wageningen Economic Research Postbus 29703

2502 LS Den Haag

T 0703358330

Ecommunications.ssg@wur.nl

www.wur.nl/economic-research

Wageningen Economic Research RAPPORT

2020-048
De missie van Wageningen University \& Research is 'To explore the potential of nature to improve the quality of life'. Binnen Wageningen University \& Research bundelen Wageningen University en gespecialiseerde onderzoeksinstituten van Stichting Wageningen Research hun krachten om bij te dragen aan de oplossing van belangrijke vragen in het domein van gezonde voeding en leefomgeving. Met ongeveer 30 vestigingen, 5.000 medewerkers en 12.000 studenten behoort Wageningen University \& Research wereldwijd tot de aansprekende kennisinstellingen binnen haar domein. De integrale benadering van de vraagstukken en de samenwerking tussen verschillende disciplines vormen het hart van de unieke Wageningen aanpak. 



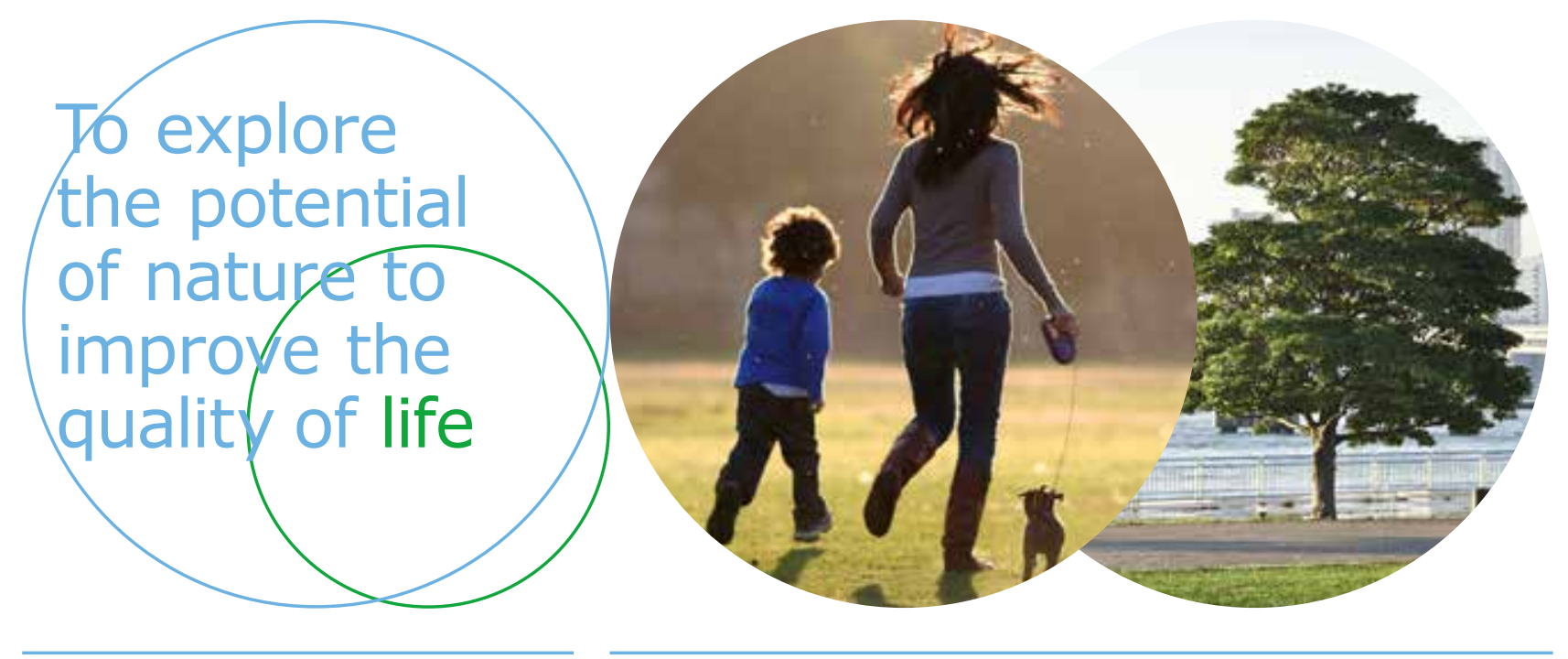

Wageningen Economic Research Postbus 29703

2502 LS Den Haag

T 0703358330

E communications.ssg@wur.nl www.wur.nl/economic-research

Rapport 2020-048

ISBN 978-94-6395-435-8
De missie van Wageningen University \& Research is 'To explore the potential of nature to improve the quality of life'. Binnen Wageningen University \& Research bundelen Wageningen University en gespecialiseerde onderzoeksinstituten van Stichting Wageningen Research hun krachten om bij te dragen aan de oplossing van belangrijke vragen in het domein van gezonde voeding en leefomgeving. Met ongeveer 30 vestigingen, 5.000 medewerkers en 12.000 studenten behoort Wageningen University \& Research wereldwijd tot de aansprekende kennisinstellingen binnen haar domein. De integrale benadering van de vraagstukken en de samenwerking tussen verschillende disciplines vormen het hart van de unieke Wageningen aanpak. 